\title{
The $\mathrm{K}^{+}$Channel $\mathrm{K}_{\mathrm{Ca}} 3.1$ as a Novel Target for Idiopathic Pulmonary Fibrosis
}

\author{
Katy Morgan Roach¹, Stephen Mark Duffy', William Coward², Carol Feghali-Bostwick ${ }^{3}$, Heike Wulff ${ }^{4}$, Peter \\ Bradding $^{1^{*}}$
}

1 Institute for Lung Health, Department of Infection, Immunity and Inflammation, University of Leicester, Leicester, United Kingdom, 2 Division of Respiratory Medicine, Centre for Respiratory Research and Nottingham Respiratory Biomedical Research Unit, University of Nottingham, Nottingham, United Kingdom, 3 Department of Medicine, Division of Pulmonary, Allergy, and Critical Care Medicine, University of Pittsburgh, Pittsburgh, Pennsylvania, United States of America, 4 Department of Pharmacology, University of California Davis, Davis, California, United States of America

\begin{abstract}
Background: Idiopathic pulmonary fibrosis (IPF) is a common, progressive and invariably lethal interstitial lung disease with no effective therapy. We hypothesised that $\mathrm{K}_{\mathrm{Ca}} 3.1 \mathrm{~K}^{+}$channel-dependent cell processes contribute to IPF pathophysiology.

Methods: $\mathrm{K}_{\mathrm{Ca}} 3.1$ expression in primary human lung myofibroblasts was examined using RT-PCR, western blot, immunofluorescence and patch-clamp electrophysiology. The role of $\mathrm{K}_{\mathrm{Ca}} 3.1$ channels in myofibroblast proliferation, wound healing, collagen secretion and contraction was examined using two specific and distinct $\mathrm{K}_{\mathrm{Ca}} 3.1$ blockers (TRAM-34 and ICA-17043 [Senicapoc]).

Results: Both healthy non fibrotic control and IPF-derived human lung myofibroblasts expressed $\mathrm{K}_{\mathrm{Ca}} 3.1$ channel mRNA and protein. $\mathrm{K}_{\mathrm{Ca}} 3.1$ ion currents were elicited more frequently and were larger in IPF-derived myofibroblasts compared to controls. $\mathrm{K}_{\mathrm{Ca}} 3.1$ currents were increased in myofibroblasts by TGF $\beta 1$ and basic $\mathrm{FGF}$. $\mathrm{K}_{\mathrm{Ca}} 3.1$ was expressed strongly in IPF tissue. $\mathrm{K}_{\mathrm{Ca}} 3.1$ pharmacological blockade attenuated human myofibroblast proliferation, wound healing, collagen secretion and contractility in vitro, and this was associated with inhibition of TGF $\beta 1-$ dependent increases in intracellular free $\mathrm{Ca}^{2+}$.

Conclusions: $\mathrm{K}_{\mathrm{Ca}} 3.1$ activity promotes pro-fibrotic human lung myofibroblast function. Blocking $\mathrm{K}_{\mathrm{Ca}} 3.1$ may offer a novel approach to treating IPF with the potential for rapid translation to the clinic.
\end{abstract}

Citation: Roach KM, Duffy SM, Coward W, Feghali-Bostwick C, Wulff H, et al. (2013) The K+ Channel $\mathrm{K}_{\mathrm{Ca}} 3.1$ as a Novel Target for Idiopathic Pulmonary Fibrosis . PLoS ONE 8(12): e85244. doi:10.1371/journal.pone.0085244

Editor: Bernard Attali, Sackler Medical School, Tel Aviv University, Israel

Received August 16, 2013; Accepted November 25, 2013; Published December 31, 2013

Copyright: (C) 2013 Roach et al. This is an open-access article distributed under the terms of the Creative Commons Attribution License, which permits unrestricted use, distribution, and reproduction in any medium, provided the original author and source are credited.

Funding: Katy Roach was supported by a PhD Studentship from the College of Medicine, Biological Sciences and Psychology, University of Leicester, United Kingdom, and project grant R270/1112 from Dunhill Medical Trust. The work was also supported in part by supported by the National Institute for Health Research Leicester Respiratory Biomedical Research Unit. The views expressed are those of the author(s) and not necessarily those of the NHS, the NIHR or the Department of Health. HW was supported by RO1 GM076063 from the National Institute of Health. The funders had no role in study design, data collection and analysis, decision to publish, or preparation of the manuscript.

Competing interests: PB has acted as an advisor to Icagen, Inc. (2007-2010). HW consulted for NeuroSearch A/S on KCa3.1 from 2009 to 2011. This does not alter the authors' adherence to all the PLOS ONE policies on sharing data and materials.

*E-mail: pbradding@hotmail.com

\section{Introduction}

Idiopathic pulmonary fibrosis (IPF) is a progressive fibrosing interstitial pneumonia of unknown etiology [1]. The term IPF is now restricted to patients with radiographic features consistent with the histological pattern of usual interstitial pneumonia (UIP). It occurs primarily in older adults [1] with an incidence of 16 per 100,000 person-years in the USA [2]. In the UK there are over 4,000 cases diagnosed annually, which is an equivalent disease burden with that of ovarian and kidney cancers [3]. There is no effective treatment[1] and prognosis is poor with a median survival of only 2-3 years from diagnosis
[3]. IPF therefore represents an important cause of morbidity and mortality and novel approaches to treatment are required urgently to address this unmet clinical need.

The pathogenic mechanisms involved in IPF initiation and progression are poorly understood [4]. Myofibroblasts play a critical role in tissue repair through cell-cell and cell-matrix interactions [5], maintaining and regulating extracellular matrix, interstitial fluid volume, and the extent of tissue contraction needed for optimum function [6]. However, dysregulated or inappropriate myofibroblast function leads to pathological scarring and tissue fibrosis [7]. The myofibroblast is the principle cell responsible for the synthesis and deposition of the 
fibrotic matrix in IPF and the associated tissue contraction [6]. Targeting pro-fibrotic myofibroblast activity therefore offers the potential to slow down or halt the progression of IPF.

Ion channels are attractive therapeutic targets in many chronic diseases. The $\mathrm{Ca}^{2+}$ activated $\mathrm{K}^{+}$channel $\mathrm{K}_{\mathrm{Ca}} 3.1$ plays an important role in $\mathrm{Ca}^{2+}$ signalling through its ability to maintain a negative membrane potential during cell activation [8]. The $\mathrm{K}_{\mathrm{Ca}} 3.1$ channel modulates the activity of several structural and inflammatory cells, including lymphocytes [9], mast cells [10], and dedifferentiated smooth muscle cells [11], through the regulation of cell proliferation [11], activation [9], migration [10] and mediator release [12]. Pharmacological inhibition or genetic deletion of $\mathrm{K}_{\mathrm{Ca}} 3.1$ prevents surgically induced renal fibrosis in mice by targeting myofibroblasts, leading to reduced collagen deposition and fibroblast proliferation while preserving renal parenchyma [13].

Both TGF $\beta 1$ and basicFGF are key growth factors which drive myofibroblast-dependent fibrosis in IPF [5,6]. We hypothesise that TGF $\beta 1$ - and basicFGF-driven $\mathrm{K}_{\mathrm{Ca}} 3.1-$ dependent cell processes are a common denominator in the pathophysiology of IPF. In this study we have investigated the expression and function of the $\mathrm{K}_{\mathrm{Ca}} 3.1$ channel in primary human lung myofibroblasts derived from both non-fibrotic and IPF lungs.

\section{Materials and Methods}

\section{Ethics statement}

All patients donating tissue gave written informed consent and the study was approved by the National Research Ethics Service (references 07/MRE08/42 and 10/H0402/12).

\section{Human lung myofibroblasts isolation and culture}

Non-fibrotic control (NFC) myofibroblasts were derived from healthy areas of lung from patients undergoing lung resection for carcinoma at Glenfield Hospital. No morphological evidence of disease was found in the tissue samples used for myofibroblast isolation. IPF myofibroblasts were derived from patients undergoing lung biopsy for diagnostic purposes at the University of Pittsburgh Medical Center, and were shown to have UIP on histological examination. Myofibroblasts were grown from explanted lung tissue from both sources under identical conditions, using Dulbecco's modified Eagle's medium (DMEM) supplemented with $10 \%$ fetal bovine serum (FBS), antibiotic/antimycotic agents and non-essential amino acids $[14,15]$. The cells were cultured at $37^{\circ} \mathrm{C}$ in $5 \% \quad \mathrm{CO}_{2} / 95 \%$ air. Cells were studied at passages $4-5$ for functional studies. All NFC patients gave informed written consent and the study was approved by the Leicestershire, Northamptonshire and Rutland Research Ethics Committee 2. Written informed consent was also obtained from all IPF subjects, in accordance with the responsible University of Pittsburgh Institutional Review Board.

\section{Human myofibroblast characterisation using immunofluorescent staining}

Human myofibroblasts were harvested from $80-90 \%$ confluent monolayers with $0.1 \%$ trypsin/0.1\% EDTA. Cells were seeded into 8-well chamber slides, grown to confluence, and immunostained using the following antibodies: FITCconjugated mouse monoclonal anti- $\alpha$-smooth muscle actin (aSMA) (F3777, $10 \mu \mathrm{g} / \mathrm{ml}$, Sigma-Aldrich, Poole, Dorset, UK) and isotype control FITC-conjugated mouse $\operatorname{lgG}_{2 a}(X 0933,10$ $\mu \mathrm{g} / \mathrm{ml}$, Dako, Ely, UK); mouse monoclonal anti-fibroblast surface protein(FSP)(F4771, $4 \mu \mathrm{g} / \mathrm{ml}$, Sigma-Aldrich) and isotype control mouse IgM (M5909, $4 \mu \mathrm{g} / \mathrm{ml}$, Sigma-Aldrich); mouse monoclonal anti-fibroblast antigen THY-1 (CP28, 3 $\mu \mathrm{g} / \mathrm{ml}$, Calbiochem, San Diego, CA) and isotope control $\operatorname{lgG}_{1}$

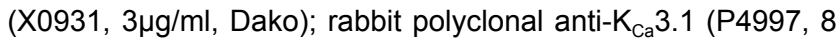
$\mu \mathrm{g} / \mathrm{ml}$, Sigma-Aldrich; M20, a gift from $\mathrm{Dr} M$ Chen, GlaxoSmithKline, Stevenage, UK), isotype control rabbit IgG (550875, BD Pharmagen, $8 \mu \mathrm{g} / \mathrm{ml}$ ). Rabbit polyclonal collagen type 1 (550346, $20 \mu \mathrm{g} / \mathrm{ml}$, Millipore, Watford, UK), isotype control rabbit $\operatorname{lgG}(20 \mu \mathrm{g} / \mathrm{ml})$. Monoclonal mouse CD68 antibody (6.4 $\mu \mathrm{g} / \mathrm{ml}$, Dako), isotype control IgG1 and CD34 R$\mathrm{PE}$ antibody $(0.5 \mu \mathrm{g} / \mathrm{ml}$, Catlag) and isotype control lgG1 R-PE was also used. Secondary antibodies labelled with FITC or RPE (F0313, Dako) were applied and the cells counterstained with 4',6-diamidino-2-phenylindole (DAPI, Sigma-Aldrich). Cells were mounted with fluorescent mounting medium and coverslipped. Original images were captured on an epifluorescent microscope (Olympus BX50, Olympus UK Ltd, Southend-onsea) and counted using Cell $F$ imaging software (Olympus UK Ltd). Matched exposures were used for isotype controls.

\section{Immunohistochemistry on human lung tissue}

Sections were cut at $4 \mu \mathrm{m}$ from paraffin-embedded diagnostic lung parenchymal biopsies or healthy control lung obtained at cancer surgery, and immunostained using mouse anti-aSMA mAb (1A4, $0.7 \mu \mathrm{g} / \mathrm{ml}$, Dako), rabbit polyclonal anti$\mathrm{K}_{\mathrm{Ca}} 3.1$ (AV35098, $5 \mu \mathrm{g} / \mathrm{ml}$, Sigma-Aldrich), or appropriate isotype control at the same concentration as the primary antibody.

\section{qRT-PCR}

Myofibroblast RNA was isolated using the RNeasy Plus Kit (Qiagen, West Sussex, UK) according to the manufacturer's instructions. $\mathrm{K}_{\mathrm{Ca}} 3.1$ gene expression was analyzed with the gene-specific Quantitect Primer Assay (Qiagen, Hilden, Germany), Hs_KCNN4_1_SG. The internal normaliser gene used was $\beta$-actin (forward primer, 5'TTCAACTCCATCATGAAGTGTGACGTG-3', reverse primer, 5'- CTAAGTCATAGTCCGCCTAGAAGCATT-3'). All expression data was normalized to $\beta$-actin and corrected using the reference dye ROX. Gene expression was quantified by real-time PCR using the Brilliant SYBR Green QRT-PCR 1Step Master Mix (Strategene, Amsterdam, The Netherlands). PCR products were run on a $1.5 \%$ agarose gel to confirm the product amplified was the correct size: $\mathrm{K}_{\mathrm{Ca}} 3.1130$ base pairs (bp), $\beta$-Actin $310 \mathrm{bp}$.

To study the effects of either TGF- $\beta 1$ (10 ng/ml, R\&D Systems, Abingdon, UK) or bFGF (10 ng/ml, R\&D Systems) on $\mathrm{K}_{\mathrm{Ca}} 3.1$ mRNA expression, cells were grown to confluence and then serum starved for $24 \mathrm{~h}$ prior to growth factor exposure for $24 \mathrm{~h}$. 


\section{Western blot}

Human myofibroblasts were disrupted in lysis buffer and soluble proteins from equivalent numbers of cells were resolved by $12 \%$ SDS-PAGE and then transferred to an immunobilon- $P$ polyvinylidene difluoride membrane. Membranes were blocked and incubated with rabbit polyclonal $\mathrm{K}_{\mathrm{Ca}} 3.1$ antibodies (Sigma antibodies P4997, AV35098 and GSK gift antibody M20. Protein bands were identified by horseradish peroxidase-conjugated secondary antibody and enhanced chemiluminescence reagent (Amersham, Little Chalfont, UK). Immunolabelled proteins were visualized using an ECL western blot detection system (GE Healthcare Life Sciences, Buckinghamshire, UK).

\section{Patch clamp electrophysiology}

The whole cell variant of the patch clamp technique was used as described previously[16,17]. The standard pipette solution contained (in $\mathrm{mM}$ ) $\mathrm{KCl}, 140 ; \mathrm{MgCl}_{2}, 2$; HEPES, 10; $\mathrm{Na}$ +-ATP, 2; GTP, 0.1 (pH 7.3). The standard external solution contained (in $\mathrm{mM}$ ) NaCl, $140 ; \mathrm{KCl}, 5 ; \mathrm{CaCl}_{2}, 2 ; \mathrm{MgCl}_{2}, 1$; HEPES, 10 (pH 7.3). For recording, myofibroblasts were placed in 35-mm dishes containing standard external solution. Whole-cell currents were recorded using an Axoclamp 200A amplifier (Axon Instruments, Foster City, CA), and currents were evoked by applying voltage commands to a range of potentials in $10 \mathrm{mV}$ steps from a holding potential of $-20 \mathrm{mV}$. Drugs were added directly to the recording chamber. To elicit $\mathrm{K}_{\mathrm{Ca}} 3.1$ currents the $\mathrm{K}_{\mathrm{Ca}} 3.1$ opener 1-ethyl-2-benzimidazolinone (1-EBIO) (Tocris, Avonmouth, UK) was used at $100 \mu \mathrm{M}$. To block $\mathrm{K}_{\mathrm{Ca}} 3.1$ currents we used the specific $\mathrm{K}_{\mathrm{Ca}} 3.1$ channel blockers 1-[(2-chlorophenyl)diphenylmethyl]-1H-pyrazole (TRAM-34) (200 nM)[18] and ICA-17043 (Senicapoc)(100 nM) [19].

\section{Human myofibroblast proliferation}

Human lung myofibroblasts $(n=4)$ were seeded into 6 well plates, when $50 \%$ confluent cells were serum starved for $24 \mathrm{~h}$ in serum-free medium. Cells were then stimulated with serumfree medium plus $0.1 \%$ DMSO, 10\% FBS medium plus $0.1 \%$ DMSO, 10\% FBS plus TRAM-34 $20 \mathrm{nM}$ and 10\% FBS plus TRAM-34 $200 \mathrm{nM}$. After 48h cells were mobilized with $0.1 \%$ trypsin $/ 0.1 \%$ EDTA and counted used a standard haemocytometer. Cell viability was assessed by trypan blue exclusion. Results were counted by 2 blinded observers with excellent agreement (intra-class correlation of 0.969). All conditions were performed in duplicate.

\section{Wound healing assay}

Human myofibroblasts were grown to confluence in 6 well plates. After $24 \mathrm{~h}$ in serum-free medium, 3 artificial wounds were scratched in each monolayer using a $200 \mu \mathrm{l}$ pipette creating a linear cell-free area. After washing, TRAM-34 (20 and $200 \mathrm{nM}$ ) and ICA-17043 (Senicapoc, a gift from Icagen Inc, Durham, NC, USA) (10 and $100 \mathrm{nM}$ ) were added (final DMSO concentration $0.1 \%$ ), and the cells stimulated with either 10 $\mathrm{ng} / \mathrm{ml} \mathrm{bFGF}$ or $10 \%$ FBS alone for $48 \mathrm{~h}$. Control wells contained $0.1 \%$ DMSO and serum-free medium alone. Cells migrating and proliferating into the wound were observed and photographs taken over $48 \mathrm{~h}$. Wound healing was analysed by measuring the area of the scraped wound using Cell $F$ software by a blinded observer (Olympus, UK), and quantified as a percentage of the starting area of the wound scraped. Data presented represents the mean of the measurements from 2 different scratches. Results were measured by 2 blinded observers with excellent agreement (intra-class correlation of 0.969).

\section{Collagen Assay}

Myofibroblasts were cultured in serum-free medium alone or $0.1 \%$ DMSO control, and stimulated with TGF $\beta 110 \mathrm{ng} / \mathrm{ml}$ in the presence of DMSO control, TRAM-34 (20 and $200 \mathrm{nM}$ ) and ICA-17043 (10 and $100 \mathrm{nM}$ ) for $16 \mathrm{~h}$. Soluble collagen released by myofibroblasts was quantified using the Sircol collagen assay (Biocolor, County Antrim, UK) according to the manufacturer's instructions [20,21].

\section{Collagen Gel Contraction}

Cells were pre-treated for 24 hours with serum-free media, 0.1\% DMSO, TRAM-34 200 nM, ICA-17043 100 nM, TRAM-7 $200 \mathrm{nM}$ or TRAM-85 $200 \mathrm{nM}$. Cells were detached and collagen gels were set up as described in [22]. TGF $\beta 1$ and bFGF were then added to appropriate wells to a final concentration of $10 \mathrm{ng} / \mathrm{ml}$. Photographs were taken at $0 \mathrm{~h}$ and $22 \mathrm{~h}$. The surface area was measured at each time point using ImageJ software (http://rsbweb.nih.gov/ij/) by 2 blinded observers with excellent agreement (intraclass correlation of 0.974).

\section{Calcium Imaging}

Changes in $\left[\mathrm{Ca}^{2+}\right]$ i were assessed with the use of a flurometric $\mathrm{Ca}^{2+}$ probe Fura-2 (Sigma-Aldrich). Myofibroblasts were grown on $35 \mathrm{~mm}$ fluorodish cell culture dishes (WPI, Hertfordshire, UK) and when $40 \%$ confluent loaded with Fura-2 for $45 \mathrm{~min}$ at $37^{\circ} \mathrm{C}$ in normal physiological saline solution (140 $\mathrm{mmol} / \mathrm{L} \mathrm{NaCl}, 5 \mathrm{mmol} / \mathrm{L} \mathrm{KCl}, 2 \mathrm{mmol} / \mathrm{L} \mathrm{CaCl}, 1 \mathrm{mmol} / \mathrm{L} \mathrm{MgCl}_{2}$, $10 \mathrm{mmol} / \mathrm{L}$ HEPES, pH 7.4 with $\mathrm{NAOH}$ ) containing $5 \mu \mathrm{mol} / \mathrm{L}$ fura-2-acetoxymethyl ester and $2.5 \mathrm{mmol} / \mathrm{L}$ probenecid. The cells were then washed and $\left[\mathrm{Ca}^{2+}\right] \mathrm{i}$ recorded using the single cell recording system previously described [23]. Data acquisition occurred at a rate of 1 dual wavelength image every second and are presented as the $340 \mathrm{~nm} / 380 \mathrm{~nm}$ ratio.

\section{Statistical analysis}

Experiments from an individual donor were performed either in duplicate or triplicate and a mean value was derived for each condition. Data distribution was tested for normality using the Kolmogorov-Smirnov test. For parametric data the 1-way ANOVA or repeated measures ANOVA for across-group comparisons was used followed by the appropriate multiple comparison post hoc test; otherwise an unpaired or paired ttest was used. Where appropriate chi-squared tests were used. For non-parametric data the Kruskal-Wallis test was used for across group comparisons with the Dunn's multiple comparison post hoc test, or the Mann Whitney $U$ test was used where 
Table 1. Clinical characteristics of NFC and IPF patients.

\begin{tabular}{|c|c|c|}
\hline Characteristic & IPF (N=9) & Non Fibrotic $(\mathrm{N}=8)$ \\
\hline \multicolumn{3}{|l|}{ Sex (no. of subjects) } \\
\hline Male & $8(90 \%)$ & $3(37.5 \%)$ \\
\hline Female & $1(10 \%)$ & $5(62.5)$ \\
\hline \multicolumn{3}{|l|}{ Age (yr) } \\
\hline Mean ( \pm SEM) & $59.77 \pm 3.39$ & $69.5 \pm 3.3$ \\
\hline Range & $40-70$ & $58-80$ \\
\hline \multicolumn{3}{|l|}{ Length of symptoms (yrs) } \\
\hline Mean ( \pm SEM) & $4.86 \pm 1.38$ & NA \\
\hline Range & $1-11$ & NA \\
\hline Smoking (no. with >10 pack/years) & 7 & 5 \\
\hline FEV 1 ( $\%$ predicted \pm SEM) & $39.56 \pm 3.675$ & $112.9 \pm 11.04$ \\
\hline FVC (\% predicted \pm SEM) & $45.63 \pm 6.074$ & $92.54 \pm 10.51$ \\
\hline DLCO (\% predicted \pm SEM) & $26.63 \pm 3$ & ND \\
\hline PA mean $(\%$ predicted \pm SEM) & $28.38 \pm 2.57$ & ND \\
\hline \multicolumn{3}{|l|}{ Treatments } \\
\hline Prednisone & 7 & 0 \\
\hline Mycophenolate Mofetil & 5 & 0 \\
\hline Azathioprine & 2 & 0 \\
\hline Methylprednisolone sodium succinate & 2 & 0 \\
\hline Tacrolimus & 2 & 0 \\
\hline \multicolumn{3}{|c|}{$\begin{array}{l}\text { This table shows the clinical characteristics of the human lung myofibroblasts } \\
\text { isolated from both the NFC }(n=8) \text { and IPF }(n=9) \text { donors. Key; NA - Not applicable, } \\
\text { ND- Not done. } \\
\text { doi: } 10.1371 \text { /journal.pone. } 0085244.001\end{array}$} \\
\hline
\end{tabular}

there were two unpaired groups. GraphPad Prism for windows (version 6, GraphPad Software, San Diego California USA) was used for these analyses. A value of $\mathrm{P}<0.05$ was taken to assume statistical significance.

\section{Results}

\section{Characterization of human lung myofibroblasts}

The clinical characteristics of the myofibroblast donors are listed in Table 1. Cultured human lung myofibroblasts displayed the typical morphology of fibroblast-related cells with a spindle or stellate shape (Figure 1). No differences in THY-1, 1B10 and aSMA expression were found between passages 2 and 4 . At passage $4,>98 \%$ of cells from all donors expressed the fibroblast marker FSP, $>97 \%$ expressed the fibroblast marker THY -1 , and $>99 \%$ expressed aSMA, confirming that these cells were almost exclusively myofibroblast in phenotype. Collagen 1 staining was present in $100 \%$ of cells (Figure 1). There was no difference between NFC and IPF cells. No cells expressed the macrophage/monocyte marker CD68 or mesenchymal cell marker CD34. All isotype controls were negative (Figure 1).

\section{Myofibroblasts express $\mathrm{K}_{\mathrm{ca}} 3.1$ channel mRNA, which is up-regulated by TGF $\beta 1$}

Human lung myofibroblasts ( $n=5$ NFC, $n=5$ IPF) expressed $\mathrm{K}_{\mathrm{Ca}} 3.1$ mRNA (Figure 2a). No difference in $\mathrm{K}_{\mathrm{Ca}} 3.1 \mathrm{mRNA}$ expression was found between passages, but all experiments were performed between passages 4 and 5 for consistency
(Figure 2b). $\mathrm{K}_{\mathrm{Ca}}$ 3.1 mRNA was significantly increased in cells from NFC compared to IPF donors (Figure 2c). TGF $\beta 1$ (10 $\mathrm{ng} / \mathrm{ml}$ ) stimulation for $24 \mathrm{~h}$ upregulated myofibroblast $\mathrm{K}_{\mathrm{Ca}} 3.1$ channel mRNA relative to $\beta$-actin, which was significantly greater in IPF compared NFC cells (Figure 2d). $\mathrm{K}_{\mathrm{Ca}} 3.1 \mathrm{mRNA}$ was up-regulated at least 8 fold in every IPF donor after TGF $\beta 1$ exposure (Figure 2e).

\section{Myofibroblasts express $\mathrm{K}_{\mathrm{ca}} 3.1$ protein}

$\mathrm{K}_{\mathrm{Ca}} 3.1$ protein expression in human lung myofibroblasts was identified by Western blot ( $n=6$ NFC, $n=5$ IPF). The predicted weight of $\mathrm{K}_{\mathrm{Ca}} 3.1$ is $48 \mathrm{kDa}$, but larger forms of $\sim 53 \mathrm{kDa}$ and several shorter splice variants exist [11,24-26]. Using two different anti- $\mathrm{K}_{\mathrm{Ca}} 3.1$ antibodies, M20 and P4997, a consistent band of $\sim 48 \mathrm{kDa}$ was observed (Figure 3a). M20 and P4997 also stained bands of $53 \mathrm{kDa}$ as described in human fibrocytes and airway smooth muscle cells [11,26], and 39kDa consistent with the presence of splice variants [25]. $\mathrm{K}_{\mathrm{Ca}} 3.1$ protein expression in myofibroblasts was also evident using immunofluorescent staining (Figure 3b).

\section{Myofibroblasts express $\mathrm{K}_{\mathrm{Ca}} 3.1$ channel currents which are increased in IPF}

At baseline, myofibroblasts from NFC and IPF donors demonstrated strong outwardly rectifying whole-cell currents, and frequent inwardly rectifying currents with features of the Kir2 family (confirmed by blocking with $10 \mu \mathrm{M}$ barium, results not shown). Interestingly, $69 \%$ of IPF cells had Kir2-like currents at baseline as opposed to $42 \%$ of NFC cells ( $P=0.0007$, chi squared).

$\mathrm{K}_{\mathrm{Ca}} 3.1$ currents in myofibroblasts were evoked using the $\mathrm{K}_{\mathrm{Ca}} 3.1$ opener 1-EBIO [27]. To block $\mathrm{K}_{\mathrm{Ca}} 3.1$ we used two distinct and selective $\mathrm{K}_{\mathrm{Ca}} 3.1$ channel blockers, TRAM-34 (Kd for $\mathrm{K}_{\mathrm{Ca}} 3.1$ block $\left.20 \mathrm{nM}\right)[18]$ and ICA-17043 (Senicapoc) $(K \mathrm{~d} \sim 10$ $\mathrm{nM})[19] . \mathrm{K}_{\mathrm{Ca}} 3.1$ currents were not present at baseline but were frequently elicited following the addition of 1-EBIO $(100 \mu \mathrm{M})$, and demonstrated the characteristic electrophysiological features of $\mathrm{K}_{\mathrm{Ca}} 3.1$ (Figure $3 \mathrm{c}$ and $\mathbf{d}$ ). In addition, the 1-EBIOinduced current was dose-dependently blocked by TRAM-34 (Figure 3c and d) and ICA-17043 (not shown) with complete block at $200 \mathrm{nM}$ and $100 \mathrm{nM}$ respectively. DMSO vehicle $(0.1 \%$ final concentration) had no effect (not shown).

The addition of 1 -EBIO elicited $\mathrm{K}_{\mathrm{Ca}} 3.1$ currents in $59 \%$ of NFC myofibroblasts ( $n=7$ donors) and $77 \%$ of IPF myofibroblasts ( $n=7$ donors $)(P=0.0411$, Chi squared). Also, the proportion of myofibroblasts per donor responding to 1-EBIO was significantly increased in IPF compared to NFC cells $(P=0.0285)$ (Figure 4a), and the size of the currents induced by 1-EBIO was significantly greater in IPF compared to NFC cells $(P=0.0054$, Mann Whitney test) (Figure $4 \mathbf{b}$ and $\mathbf{c})$. Thus, functional $\mathrm{K}_{\mathrm{Ca}} 3.1$ channels were expressed more frequently and the currents were larger in myofibroblasts derived from IPF lung tissue compared to NFC tissue.

Measurements of myofibroblast capacitance were unreliable due to the relatively large cell size, so it was not possible to calculate current density. 


\section{Figure 1}
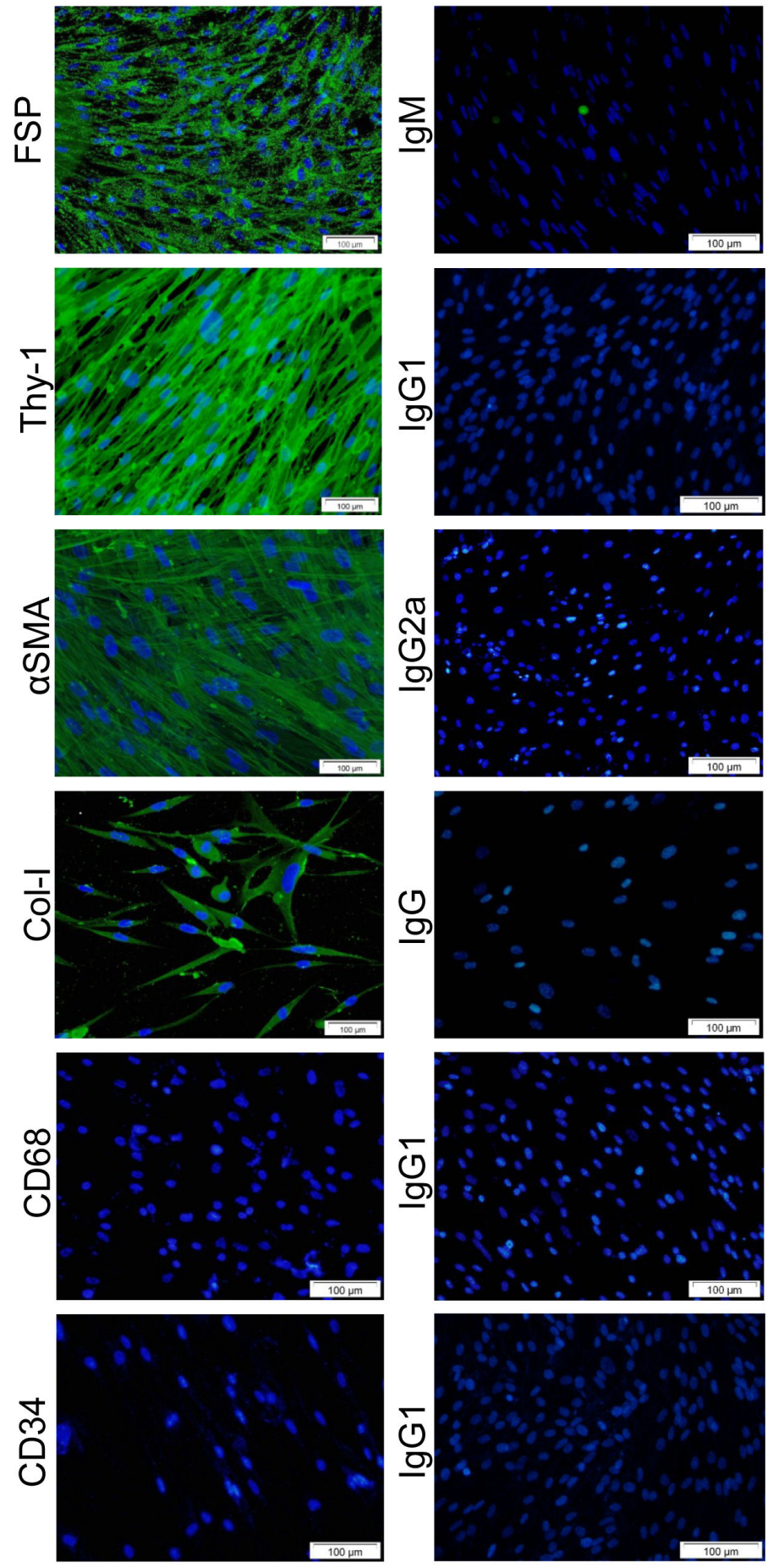

Figure 1. Characterization of human lung myofibroblasts by immunofluorescence. Primary human lung myofibroblast cultures between passages 4 and 5 were stained with myofibroblast markers. Representative images are shown for: anti-fibroblast surface protein (FSP) and the mouse isotype control IgM; anti-fibroblast antigen which recognises the fibroblast antigen (thy-1/ CD90) and the mouse isotype control IgG1; $\alpha$-smooth muscle actin, and the isotype control IgG2a; collagen type 1 antibody and rabbit isotype control IgG; CD68 cell staining was negative; and corresponding isotype control lgG3, indicating that there is no contamination of monocytes or macrophage cells; CD34 antibody shows negative staining as does the appropriate isotype control IgG1. Nuclei are stained with DAPI.

doi: 10.1371/journal.pone.0085244.g001 


\section{Figure 2}

a)

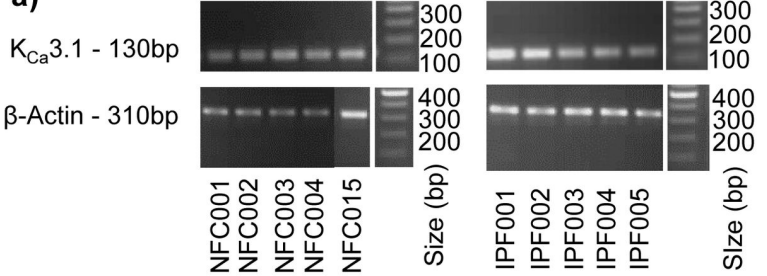

b)

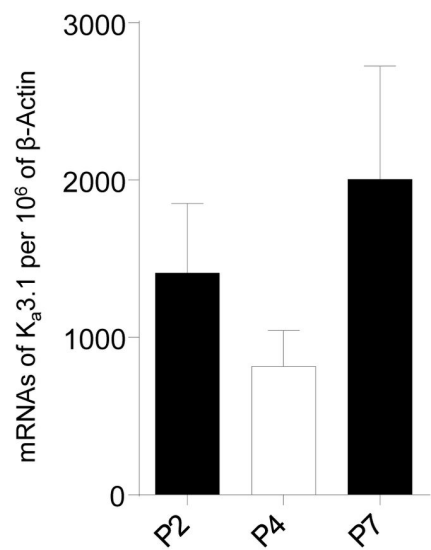

d)

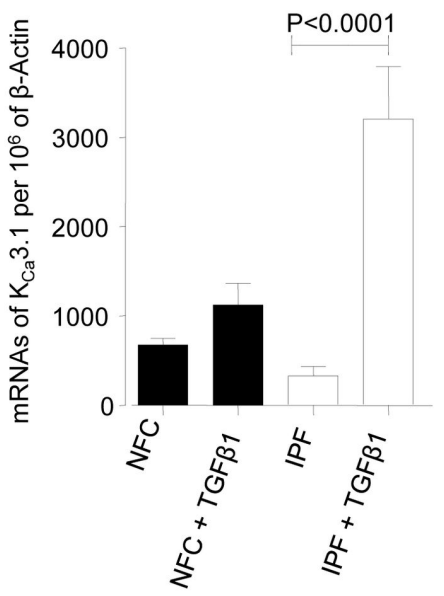

c)

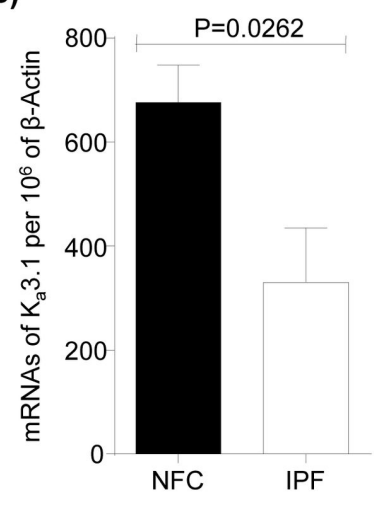

e)

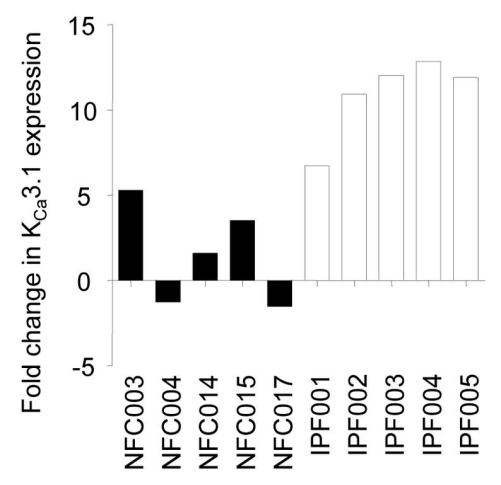

Figure 2. $\mathrm{K}_{\mathrm{Ca}} 3.1$ channel mRNA is expressed by myofibroblasts and upregulated following TGF $\beta 1$ stimulation. a) Products from quantitative real-time PCR for $\mathrm{K}_{\mathrm{ca}} 3.1$ were visualized on a $1.5 \%$ agarose gel to confirm that only one product was amplified and that it was the correct size (130 bp). $\beta$-Actin was used as the normalizing control ( $310 \mathrm{bp})$. b) In preliminary experiments we examined the mRNA expression levels of $\mathrm{K}_{\mathrm{Ca}} 3.1$ in the NFC donors at passages 2, 4 and 7 and again found no significant differences. To be sure that passage number had no effect all experiments were performed between passages 4 and 5 . Data represent mean $\pm S E M$. c) Quantitative real-time PCR showed that $\mathrm{K}_{\mathrm{Ca}} 3.1 \mathrm{mRNA}$ expression was greater in NFC donors ( $\left.n=5\right)$ than IPF donors ( $n=5), P=0.0262$ (unpaired t test). d) $\mathrm{K}_{\mathrm{Ca}} 3.1$ mRNA expression increased after TGF $\beta 1$ stimulation (All groups; 1 -way ANOVA, $P<0.0001)$, NFC donors $(n=5)$, IPF donors $(n=5)$. There was a highly significant increase in IPF myofibroblasts following $24 \mathrm{~h}$ of TGF $\beta 1$ stimulation. $P<0.0001$ (corrected by Bonferroni's multiple comparison test). e) Quantitative real-time PCR demonstrating the relative fold increase in NFC and IPF myofibroblasts after stimulation with TGF $\beta 1$. Following normalization with $\beta$ actin there was a relative fold increase in $\mathrm{K}_{\mathrm{Ca}} 3.1$ expression in all IPF donors. Results were calculated using the $\delta \delta C T$ method. Data represented as \pm SEM for Figure $1 b, c$ and $d$.

doi: 10.1371/journal.pone.0085244.g002 
Figure 3

a)

$\mathrm{K}_{\mathrm{Ca}} 3.1$

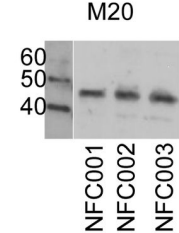

P4997

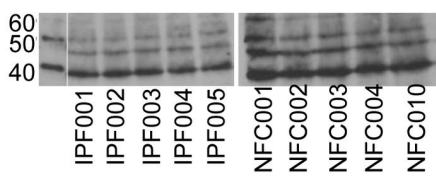

b)
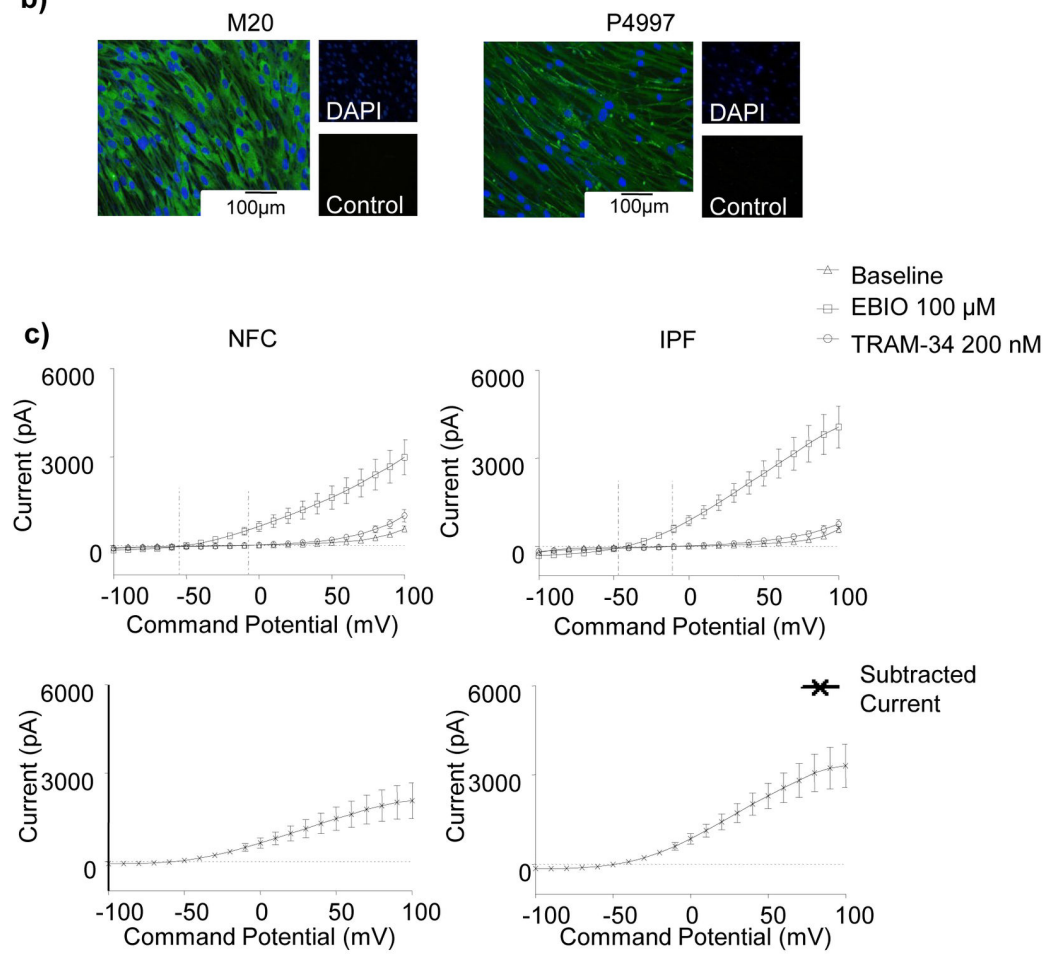

d)
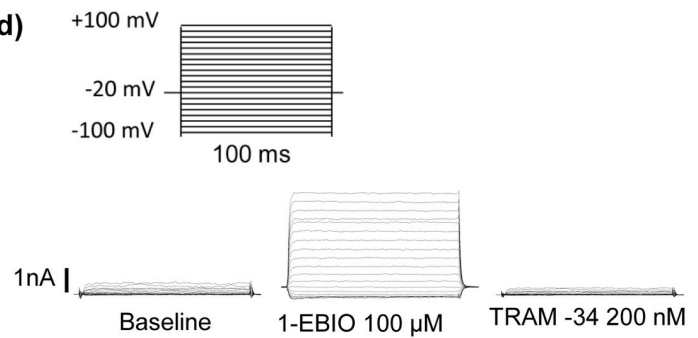

Figure 3. $\mathrm{K}_{\mathrm{ca}} 3.1$ channel protein is present within myofibroblasts and $\mathrm{K}_{\mathrm{ca}} 3.1$ channels are functional. a) Western blot of human lung myofibroblast lysates using 2 different $\mathrm{K}_{\mathrm{Ca}} 3.1$ channel antibodies, M20 and P4997. All images show a consistent band at the predicted size for the $\mathrm{K}_{\mathrm{Ca}} 3.1$ channel at $48 \mathrm{KDa}$ in human lung myofibroblasts. An additional band at $53 \mathrm{kDa}$ is present as described in other cell types. b) Example of immunofluorescent staining for $\mathrm{K}_{\mathrm{Ca}} 3.1$ in NFC myofibroblasts using M20 and P4997 antibodies. DAPI nuclear staining and negative rabbit isotype control IgG are shown. c) Whole-cell patch-clamp electrophysiology recordings of $\mathrm{K}_{\mathrm{Ca}} 3.1$ in NFC $(n=14)$ and IPF $(n=13)$ human lung myofibroblasts activated with 1-EBIO and blocked with TRAM-34 $(200 \mathrm{nM})$. Upper panels: Mean \pm SEM current voltage curves demonstrate a small outwardly rectifying current at baseline, and the IPF donors have a relatively small inwardly rectifying Kir current (confirmed by blocking with $10 \mu \mathrm{M}$ barium, results not shown). Large currents with a negative reversal potential develop after the addition of the $\mathrm{K}_{\mathrm{Ca}} 3.1$ opener 1-EBIO (100 $\left.\mu \mathrm{M}\right)$, which are blocked by the selective $\mathrm{K}_{\mathrm{Ca}} 3.1$ blocker TRAM-34 (200 nM). Lower panels: The subtracted (1-EBIO minus TRAM-34) TRAM-34sensitive $\mathrm{K}_{\mathrm{Ca}} 3.1$ current. d) The voltage protocol and the raw current are demonstrated showing typical electrophysiological features of $\mathrm{K}_{\mathrm{Ca}} 3.1$ in a myofibroblast.

doi: 10.1371/journal.pone.0085244.g003 


\section{Figure 4}

a)

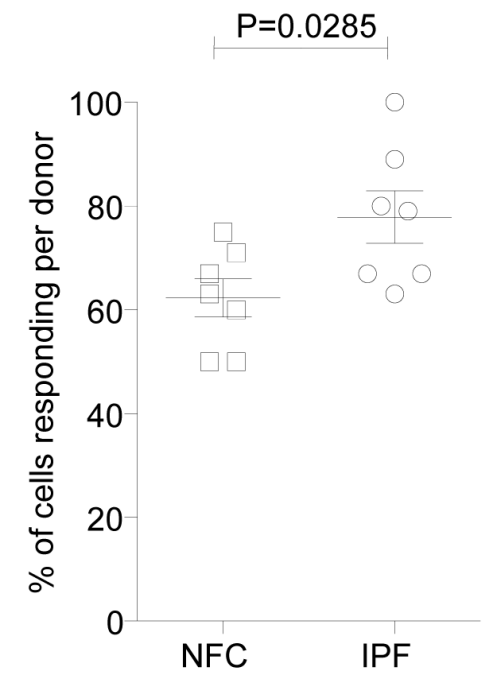

c)

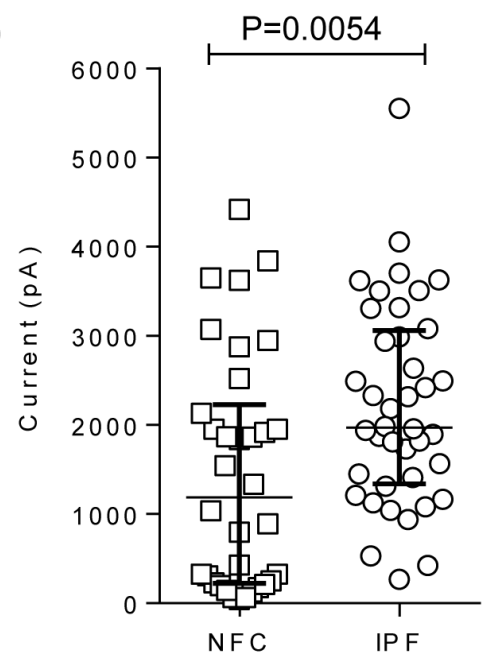

b)
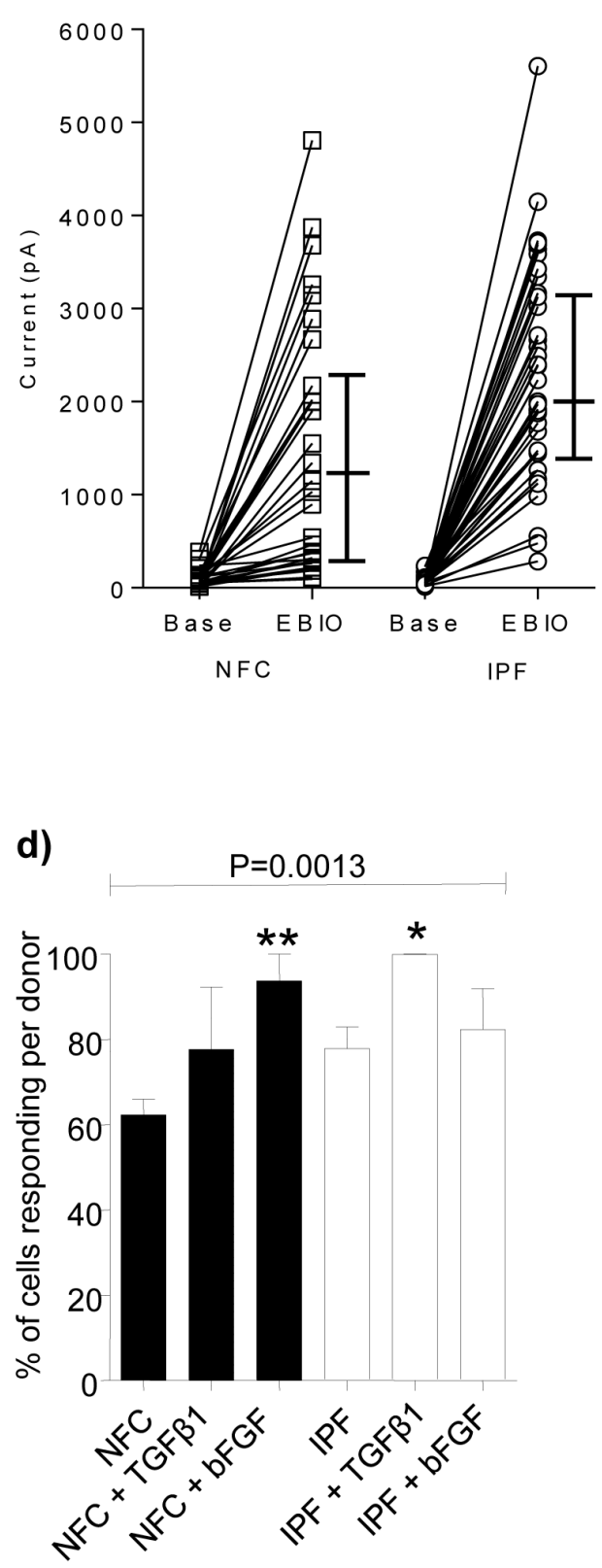

Figure 4. Functional $\mathrm{K}_{\mathrm{ca}} 3.1$ channels demonstrate greater expression in IPF myofibroblasts compared to NFC myofibroblasts and channel expression is increased by pro-fibrotic growth factors. a) The mean percentage of IPF myofibroblasts per donor developing a $\mathrm{K}_{\mathrm{Ca}} 3.1$ current in response to 1-EBIO was significantly higher than in NFC myofibroblasts $(P=0.0285$, unpaired t-test). Data presented as mean \pm SEM. b) The whole-cell current at $+40 \mathrm{mV}$ before and after the addition of 1 EBIO in all responding NFC and IPF human lung myofibroblasts. Data presented as median and IQR. c) The subtracted (1-EBIO minus baseline) 1 -EBIO-dependent $\mathrm{K}_{\mathrm{Ca}} 3.1$ current at $+40 \mathrm{mV}$ was significantly larger in IPF cells than in NFC cells $(P=0.0054$, Mann Whitney test). Data presented as median and IQR. d) The mean percentage of NFC and IPF myofibroblasts expressing $\mathrm{K}_{\mathrm{Ca}} 3.1$ currents increased after stimulation with TGF $\beta 1$ and bFGF (All groups; 1 -way ANOVA, $P=0.0013$ ). The proportion of IPF cells responding to $1-\mathrm{EBIO}$ after TGF $\beta 1$ stimulation was significantly higher $\left({ }^{*} P=0.0336\right.$, corrected by Bonferroni's multiple comparisons test). Significantly more NFC cells responded to 1-EBIO following bFGF stimulation $\left({ }^{* *} P=0.0035\right.$, corrected by Bonferroni's multiple comparisons test). Data presented as mean \pm SEM.

doi: 10.1371/journal.pone.0085244.g004 
The proportion of myofibroblasts expressing $\mathrm{K}_{\mathrm{ca}} 3.1$ currents increases following mitogenic stimulation

After $24 \mathrm{~h}$ of stimulation with $10 \mathrm{ng} / \mathrm{ml}$ basic fibroblast growth factor (bFGF), a greater proportion of myofibroblasts from NFC tissue expressed $\mathrm{K}_{\mathrm{Ca}} 3.1$ currents in comparison to unstimulated cells ( $P=0.0035$, corrected by Bonferroni's multiple comparisons test), indicating increased functional channel expression. Similar results were seen in IPF myofibroblasts using TGF $\beta 1(P=0.0336$, corrected by Bonferroni's multiple comparisons test) (Figure 4d).

\section{$\mathrm{K}_{\mathrm{Ca}} 3.1$ immunoreactivity is expressed in IPF parenchymal lung tissue}

There was strong immunostaining for $\mathrm{K}_{\mathrm{Ca}} 3.1$ in NFC lung tissue $(n=3)$, particularly in airway and alveolar epithelial cells, but also in cells within the interstitium including vessels and inflammatory cells (Figure $\mathbf{5 a}$ ). $\mathrm{K}_{\mathrm{Ca}} 3.1$ was also expressed strongly in areas of parenchymal fibrosis in IPF and colocalised with areas of aSMA positivity ( $n=5$, IPF) (Figure 5b). As there is no control for parenchymal fibrosis, we did not compare the magnitude of $\mathrm{K}_{\mathrm{Ca}} 3.1$ staining between NFC and IPF tissue.

\section{$\mathrm{K}_{\mathrm{Ca}} 3.1$ channel inhibition inhibits myofibroblast proliferation}

Stimulation with $10 \%$ FBS for $48 \mathrm{~h}$ significantly increased myofibroblast proliferation over control $(P=0.0040$, corrected by Bonferroni's multiple comparisons test), in both NFC and IPF donors, and to the same extent. However, $\mathrm{K}_{\mathrm{Ca}} 3.1$ blockade with TRAM-34 (200 nM) inhibited FBS-induced proliferation ( $P=0.0076$, corrected by Bonferroni's multiple comparisons test)(Figure 6a).

\section{Selective pharmacological blockade of $\mathrm{K}_{\mathrm{ca}} 3.1$ attenuates wound healing}

Myofibroblast wound healing was assessed in a 2-D scratch assay (Figure 6b). Myofibroblasts stimulated with 10\% FBS showed enhanced wound repair compared to media alone $(P<0.0001$, paired t-test). There was no difference between NFC- and IPF-derived cells and all data are pooled (Figure 6c). Wound healing in the absence of FBS or bFGF was not affected by $\mathrm{K}_{\mathrm{Ca}} 3.1$ blockade (Figure $6 \mathrm{~d}$ ) and no inhibition of wound healing was seen with two structurally related molecules without channel blocking activity, TRAM-85 and TRAM-7 (Figure 6e)[13,28].

FBS-induced wound repair was dose-dependently attenuated by both TRAM-34 and ICA-17043 (repeated measures ANOVA, $P<0.0001$ and $P=0.0095$ respectively) (Figure $7 \mathbf{a}$ and $\mathbf{b}$ ). Thus, in $10 \% \mathrm{FBS}$, total wound healing decreased by (mean \pm SEM) $30.6 \pm 5.4 \%$ with TRAM-34 $200 \mathrm{nM}$ and by $17.2 \pm 5.9 \%$ with ICA-17043 $100 \mathrm{nM}$; this was equivalent to inhibition of the FBS-dependent response by $75.7 \pm 10.9 \%$ and $47.9 \pm 15.3 \%$ respectively.

Compared to unstimulated cells, bFGF $(10 \mathrm{ng} / \mathrm{ml})$ also increased myofibroblast wound healing over $48 \mathrm{~h}$ in both NFC and IPF donors ( $P=0.002$, paired t-test). bFGF-induced wound repair was dose-dependently attenuated by ICA-17043 (repeated measures ANOVA, $P=0.0076$ )(Figure 7c). At $48 \mathrm{~h}$, total wound healing was reduced by $24.4 \pm 6.6 \%$ in the presence of ICA-17043 $100 \mathrm{nM}$ compared to DMSO control (equivalent to inhibition of the FGF-dependent response by $63.4 \pm 13.4 \%$ ). In summary, mitogen-induced wound healing of human lung myofibroblasts is attenuated by $\mathrm{K}_{\mathrm{Ca}} 3.1$ channel block.

\section{TGF $\beta 1$-dependent collagen production in human myofibroblasts is attenuated by $\mathrm{K}_{\mathrm{Ca}} 3.1$ blockade}

Myofibroblasts from both IPF and NFC lung secreted similar amounts of collagen in response to TGF $\beta 1(10 \mathrm{ng} / \mathrm{ml})$. This was markedly attenuated by both TRAM-34 and ICA-17043 (Figure $8 \mathbf{a}$ and $\mathbf{b}$ ), but was not affected by TRAM-85 or TRAM-7 (Figure 8c).

\section{$\mathrm{K}_{\mathrm{Ca}} 3.1$ inhibition attenuates TGF- $\beta 1$ and $\mathrm{bFGF}$ induced myofibroblast contraction}

Myofibroblasts cultured in collagen gels from both IPF and NFC donors contracted following TGF $\beta 1$ stimulation and bFGF stimulation (Figure 9). After dose response experiments were performed, $10 \mathrm{ng} / \mathrm{ml}$ chosen as the optimal concentration for each growth factor (Figure $\mathbf{9 a}$ and $\mathbf{b}$ ). There was no difference between NFC- and IPF-derived cells (Figure 9c,) and all data are therefore pooled. TGF $\beta 1$ stimulation increased myofibroblast contraction from (mean \pm SEM) $30.6 \pm 3.6 \%$ to $48.6 \pm 2.4 \%$, and bFGF stimulation increased myofibroblast contraction from $31.7 \pm 3.8 \%$ to $51.2 \pm 4.8 \%$. Compared to DMSO control, pre-treatment for $24 \mathrm{~h}$ in the presence of either TRAM-34 $200 \mathrm{nM}$ or ICA-17043 $100 \mathrm{nM}$ almost completely inhibited both TGF $\beta 1$ - and bFGF-stimulated myofibroblast contraction (Figure 10a-d). In contrast, the control molecules TRAM-7 and TRAM-85 were without effect (not shown).

TRAM-34 and ICA-17043 did not inhibit baseline constitutive myofibroblast contraction significantly in the absence of growth factors (Figure 9d and e), indicating that TRAM-34 and ICA-17043 only inhibit TGF $\beta 1$ - or bFGF-dependent myofibroblast contraction.

\section{$\mathrm{K}_{\mathrm{Ca}} 3.1$ regulates myofibroblast pro-fibrotic functions by} inhibiting TGF $\beta 1$ induced increases in $\left[\mathrm{Ca}^{2+}\right] \mathbf{i}$

Open $\mathrm{K}_{\mathrm{ca}} 3.1$ channels hyperpolarise plasma membranes which in turn promotes $\mathrm{Ca}^{2+}$ influx [12]. This is believed to account for the ability of $\mathrm{K}_{\mathrm{Ca}} 3.1$ inhibition to attenuate many diverse cell responses. To investigate the underlying mechanism behind the attenuation of pro-fibrotic myofibroblast function with $\mathrm{K}_{\mathrm{Ca}} 3.1$ blockers, we therefore investigated whether changes in $\left[\mathrm{Ca}^{2+}\right] \mathrm{i}$ occur following stimulation with TGF $\beta 1$. TGF $\beta 1$ (10 ng/ml) elicited an immediate, rapid rise in $\left[\mathrm{Ca}^{2+}\right] \mathrm{i}$ in $100 \%$ of IPF cells and $53 \%$ of NFC cells. There was a significant increase in $\left[\mathrm{Ca}^{2+}\right]$ i for both IPF $(n=33, P<0.0001)$ and NFC $(n=28, P<0.0001)(F i g u r e ~ 11 a)$. In the IPF donors only, TRAM-34 was added 5 minutes prior to the addition of TGF $\beta 1$ which inhibited the TGF $\beta 1$ induced rise in $\left[\mathrm{Ca}^{2+}\right]$ i (Figure 11b). The change in $\left[\mathrm{Ca}^{2+}\right]$ i following TGF $\beta 1$ stimulation was significantly reduced with 5 minutes pre-treatment of TRAM-34 $200 \mathrm{nM}$ compared to controls, $\mathrm{P}<0.0001$ (Figure 11c). Cells were also treated with $0.1 \%$ DMSO control which had no effect 


\section{Figure 5}

\section{a)}
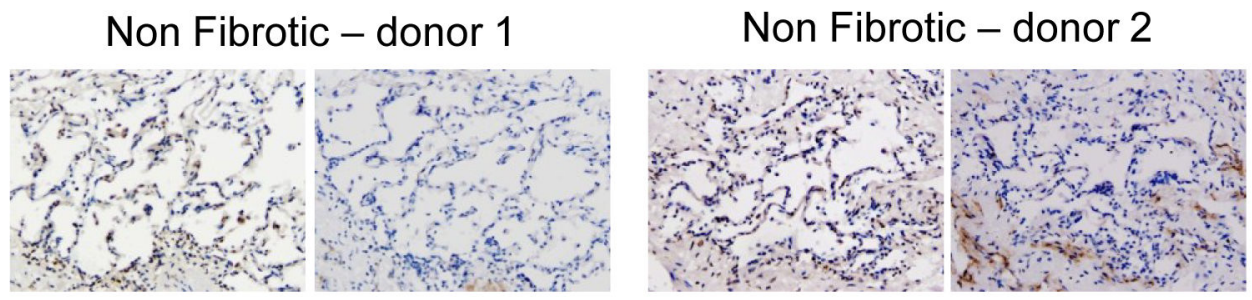

$$
\mathrm{K}_{\mathrm{Ca}} 3.1
$$

aSMA

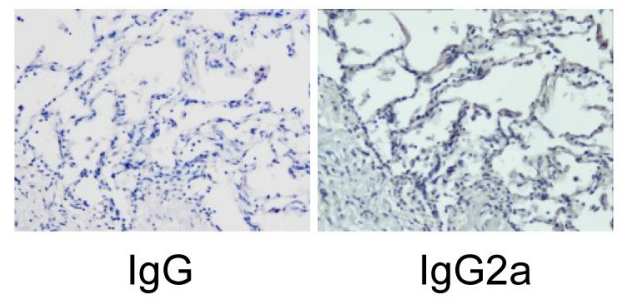

$\mathrm{K}_{\mathrm{Ca}} 3.1$

aSMA

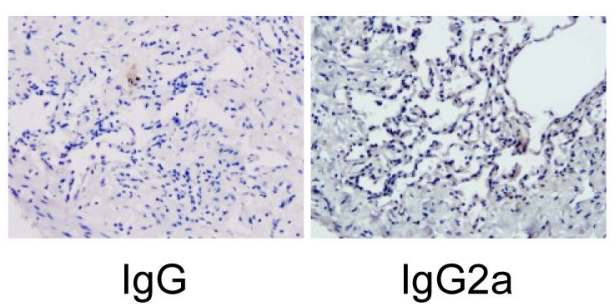

b)

IPF donor 1

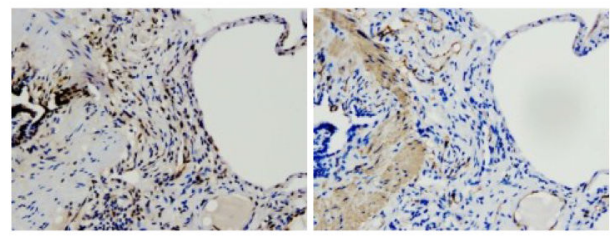

$\mathrm{K}_{\mathrm{Ca}} 3.1$

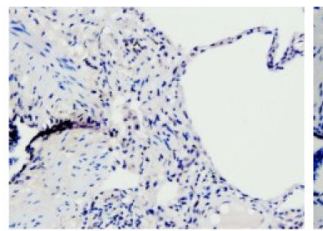

IgG
aSMA

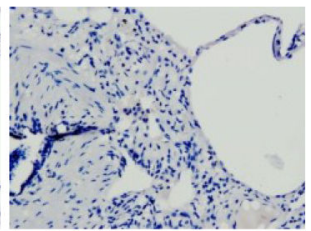

$\lg G 2 a$

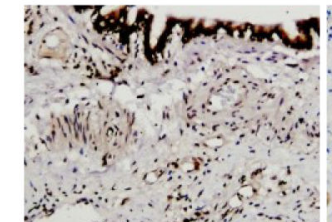

IPF donor 2

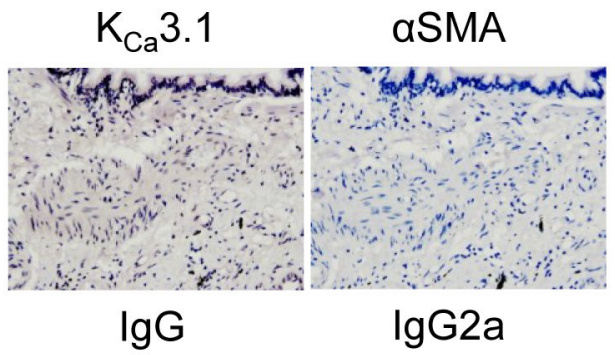

Figure 5. $\mathrm{K}_{\mathrm{Ca}} 3.1$ expression within human lung tissue of non-fibrotic and IPF patients. a) Representative $\mathrm{K}_{\mathrm{Ca}} 3.1$ and $\alpha \mathrm{SMA}$ immunostaining of healthy lung parenchyma from two NFC tissue donors. All pictures are from sequential sections. Isotype controls are negative. b) Representative immunostaining of lung parenchyma from two IPF tissue donors demonstrating $\mathrm{K}_{\mathrm{Ca}} 3.1$ and $\alpha \mathrm{SMA}$ immunostaining in areas of fibrosis. All pictures are from sequential sections. $\mathrm{K}_{\mathrm{Ca}} 3.1$ channel expression is particularly strong in the epithelium and within and surrounding areas positive for aSMA.

doi: 10.1371/journal.pone.0085244.g005

on subsequent TGF $\beta 1$-dependent increase in $\left[\mathrm{Ca}^{2+}\right]_{1}$, data no shown.

\section{Discussion}

There are three major, novel findings from this study. Firstly we have performed the first detailed electrophysiological 
Figure 6
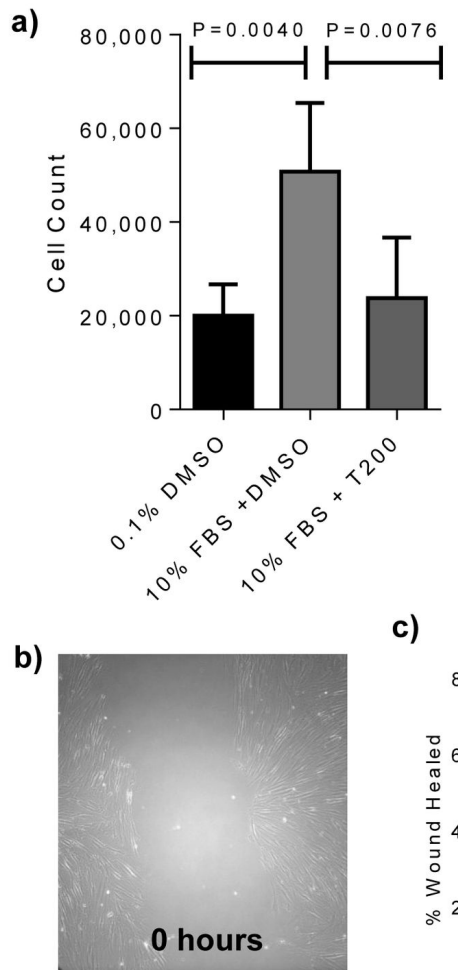

c)
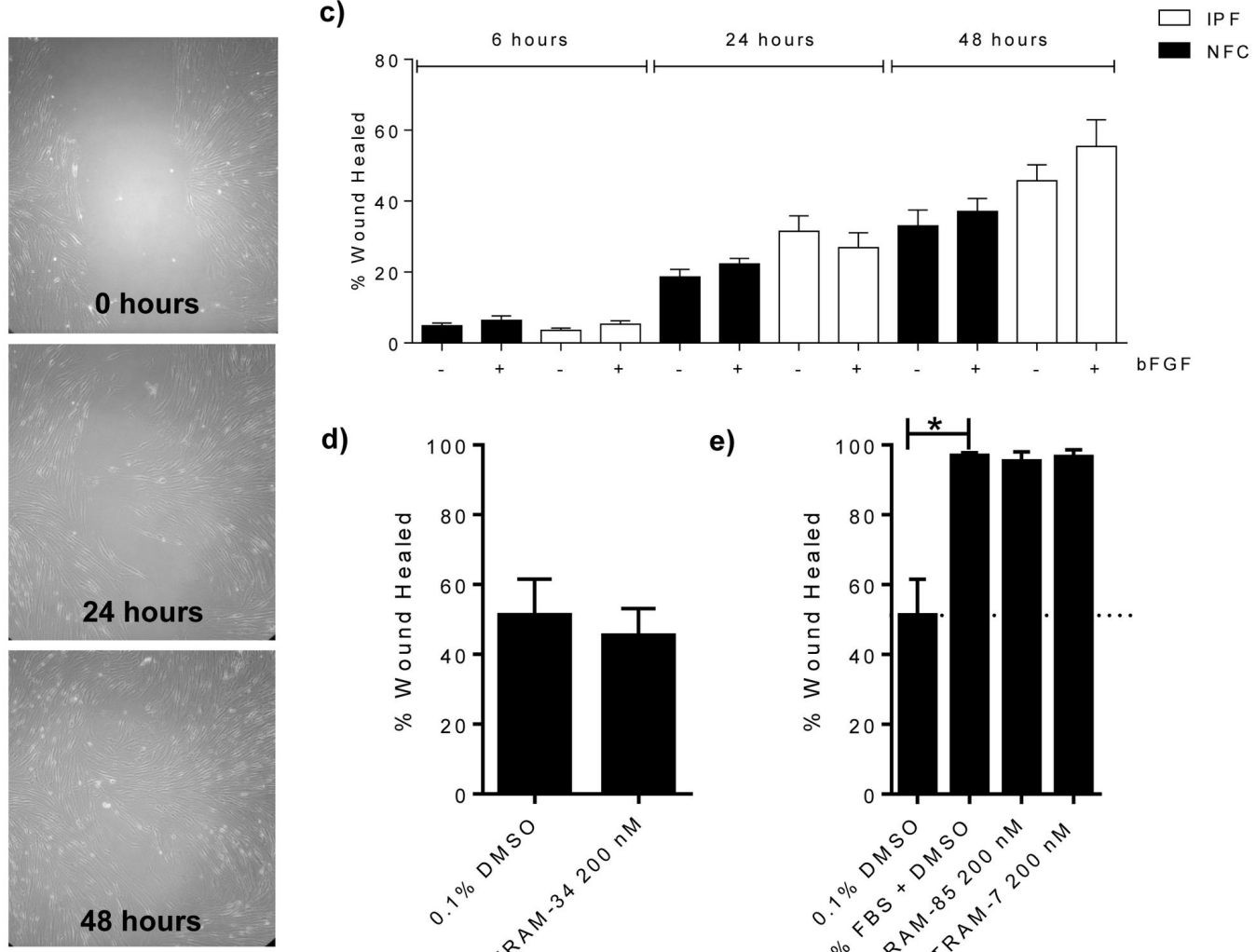

d)

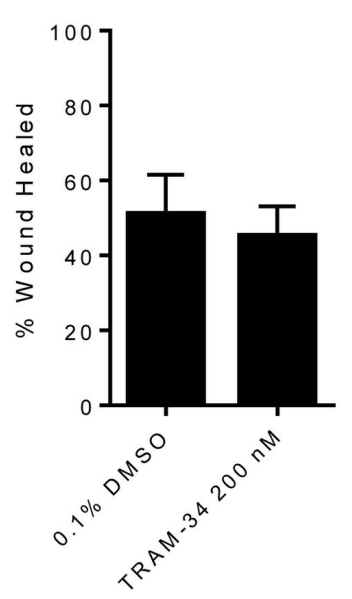

e)

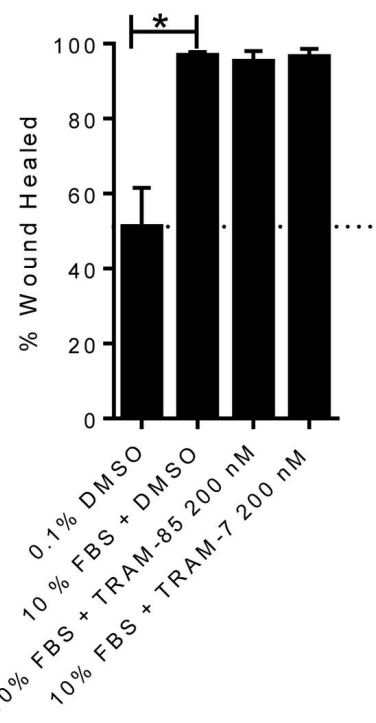

Figure 6. Myofibroblast proliferation is inhibited by $\mathrm{K}_{\mathrm{ca}} 3.1$ channel block. Constitutive unstimulated wound healing is not altered by $\mathrm{K}_{\mathrm{Ca}} 3.1$ blockade, and growth factor-stimulated healing is not inhibited by TRAM-7 or TRAM-85 .

a) Myofibroblast proliferation was increased following 48h of stimulation with FBS and significantly reduced by TRAM-34 (200 nM). b) An example of the wound created in a confluent monolayer of myofibroblasts in the wound healing assay and how it heals over the 48 hours. c) This graph displays that over the time course of the wound healing assay no significant differences were found between NFC and IPF donors in response bFGF, similar results were seen with FBS but results are not shown. d) TRAM-34 does not inhibit wound healing in the absence of mitogenic stimulation. e) FBS significantly increases wound healing $\left({ }^{*} P=0.0168\right.$, Paired t-test) but the molecules TRAM-7 and TRAM- 85 which are structurally related to TRAM-34 do not have $\mathrm{K}_{\mathrm{Ca}} 3.1$ channel-blocking activity and do not inhibit mitogen-dependent wound healing. Data represent mean $\pm S E M$ for all figures a, $c, d$ and e.

doi: 10.1371/journal.pone.0085244.g006 


\section{Figure 7}

a)

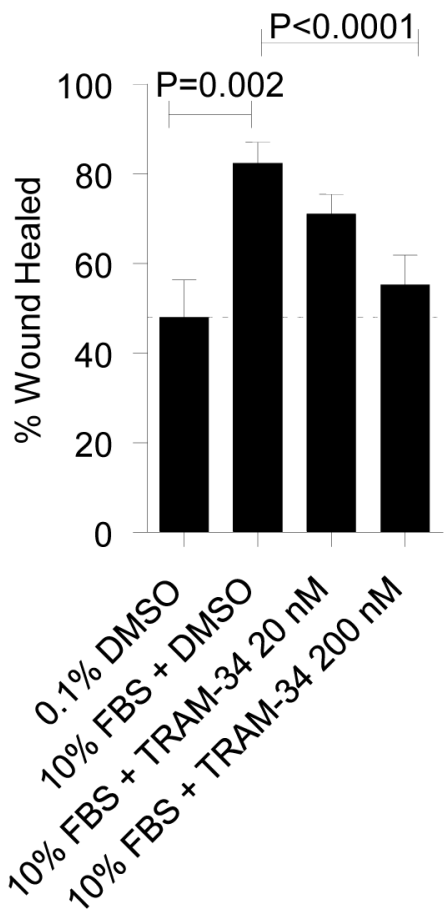

b)

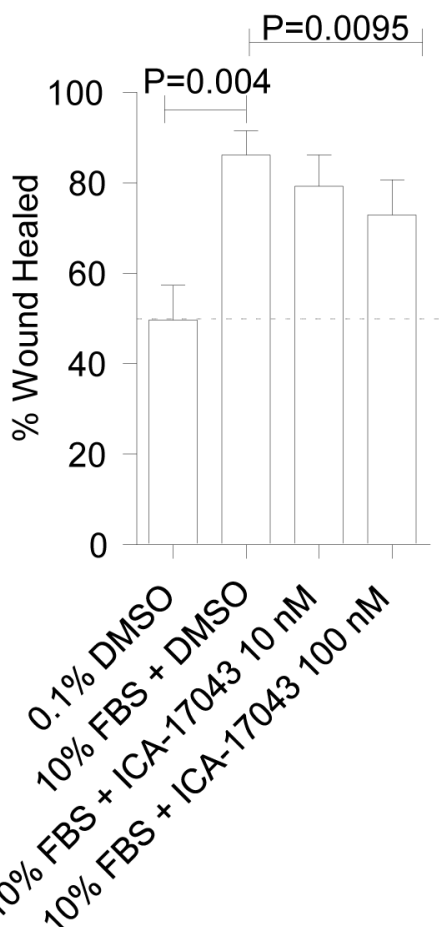

c)

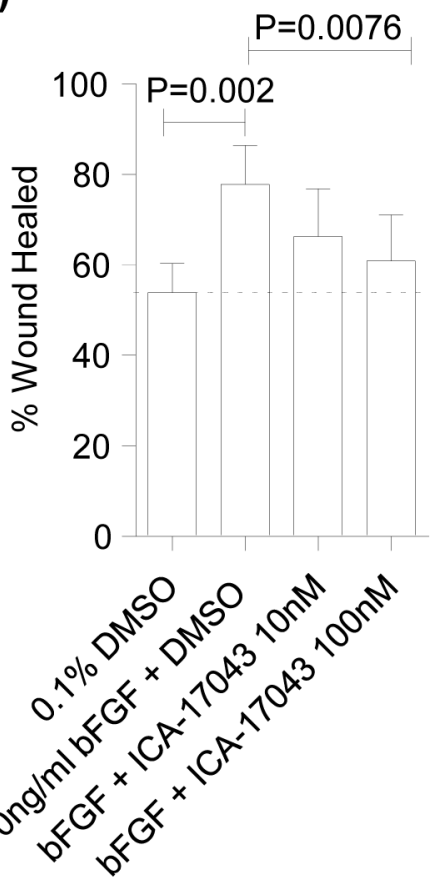

Figure 7. Blocking $\mathrm{K}_{\mathrm{Ca}} 3.1$ with TRAM-34 and ICA-17043 induces a dose-dependent attenuation of myofibroblast wound healing. a) and b) Myofibroblasts stimulated with 10\% FBS and 0.1\% DMSO vehicle control, showed accelerated wound healing in comparison to $0.1 \%$ DMSO alone $(P=0.002$, and $P=0.004$ respectively, paired t-test). There was a dose-dependent decrease in FBS-induced wound healing over $48 \mathrm{~h}$ in the presence of either a) TRAM-34 (20 nM and $200 \mathrm{nM})(P<0.0001$, repeated measures ANOVA) or b) ICA-17043 (10 $\mathrm{nM}$ and $100 \mathrm{nM})(P=0.0095$, repeated measures ANOVA). c) Myofibroblast wound healing in response to $10 \mathrm{ng} / \mathrm{ml} \mathrm{bFGF}$ and $0.1 \%$ DMSO stimulation at $48 \mathrm{~h}$ was increased in comparison to media alone $\left({ }^{*} P=0.002\right.$, paired $\mathrm{t}$ test). There was a dose-dependent decrease in wound healing over the $48 \mathrm{~h}$ in the presence ICA-17043 ( $P=0.0076$, Repeated measures ANOVA). Data represented as mean \pm SEM for all the above figures.

doi: 10.1371/journal.pone.0085244.g007

analysis of primary human parenchymal myofibroblasts from both NFC and IPF lung, and show for the first time that these cells express the $\mathrm{Ca}^{2+}$-activated $\mathrm{K}^{+}$channel $\mathrm{K}_{\mathrm{Ca}} 3.1$ in both health and disease. Secondly we demonstrate that pharmacological blockade of $\mathrm{K}_{\mathrm{Ca}} 3.1$ inhibits human lung myofibroblast pro-fibrotic activity such as proliferation wound healing, collagen secretion and growth factor-dependent contraction. Thirdly, TGF $\beta 1$-induced myofibroblast pro-fibrotic function is associated with $\mathrm{K}_{\mathrm{Ca}} 3$.1-dependent regulation of $\left[\mathrm{Ca}^{2+}\right]$ i. These findings highlight the importance of the $\mathrm{K}_{\mathrm{Ca}} 3.1$ channel and $\mathrm{Ca}^{2+}$ signaling in the growth factor-dependent profibrotic functions of human lung myofibroblasts.

The widely accepted markers of a myofibroblast are that it co-expresses fibroblast-associated markers and aSMA fibres [6]. The cells studied in these experiments were predominantly of a myofibroblast phenotype, a finding consistent with the parenchymal lung myofibroblast phenotype described by others $[29,30]$.
$\mathrm{K}_{\mathrm{Ca}} 3.1$ channel mRNA, protein and functional channels were expressed in myofibroblasts derived from both NFC and IPF donors. Interestingly, $\mathrm{K}_{\mathrm{Ca}} 3.1$ currents were present more frequently in IPF lung myofibroblasts and these currents were larger when compared to NFC lung myofibroblasts. This might reflect $\mathrm{K}_{\mathrm{Ca}} 3.1$ up-regulation driven by the initiating disease insult in vivo, but the cells studied had been through 4 passages of culture, raising the possibility of an underlying disease-predisposing difference in myofibroblast $\mathrm{K}_{\mathrm{Ca}} 3.1$ activity in patients with IPF. Surprisingly, although $\mathrm{K}_{\mathrm{Ca}} 3.1$ currents were increased in IPF myofibroblasts, $\mathrm{K}_{\mathrm{Ca}} 3.1$ mRNA was decreased. However, chronic exposure of cells to the $\mathrm{K}_{\mathrm{Ca}} 3.1$ opener 1EBIO down-regulates $\mathrm{K}_{\mathrm{Ca}} 3.1$ mRNA expression [31,32], suggesting a negative-feedback mechanism which is perhaps operative here. Whether the increased $\mathrm{K}_{\mathrm{Ca}} 3.1$ plasma membrane expression in IPF myofibroblasts represents increased trafficking to the cell membrane or decreased turnover requires further study. 


\section{Figure 8}

a)

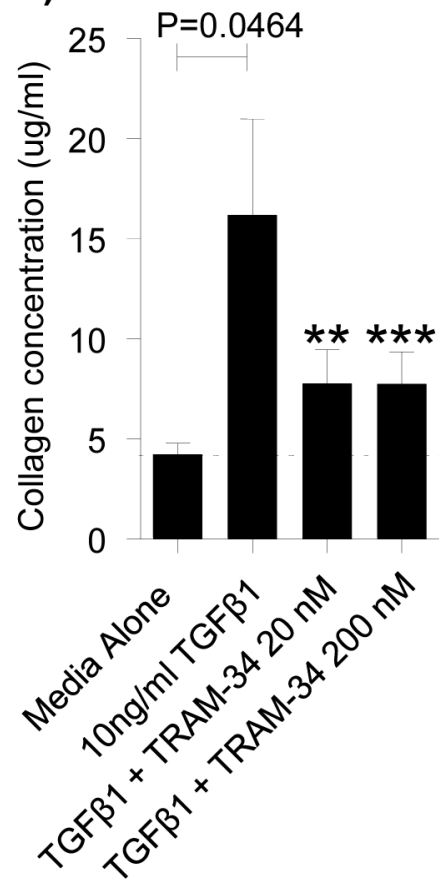

b)
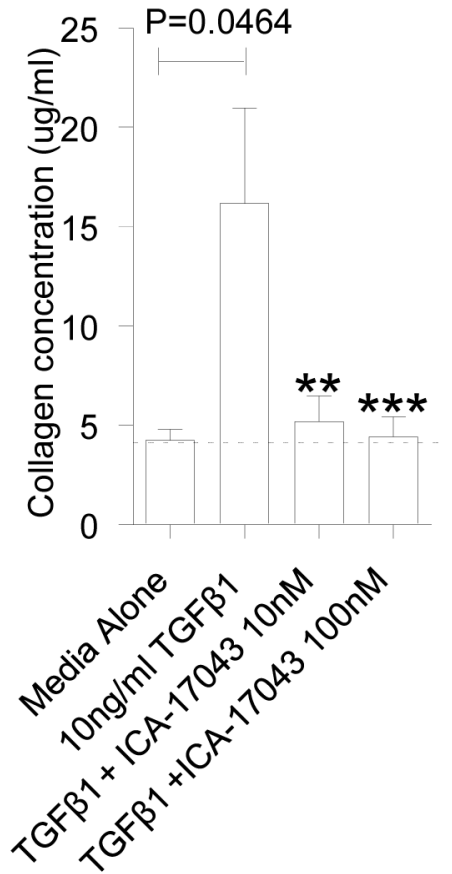

c)

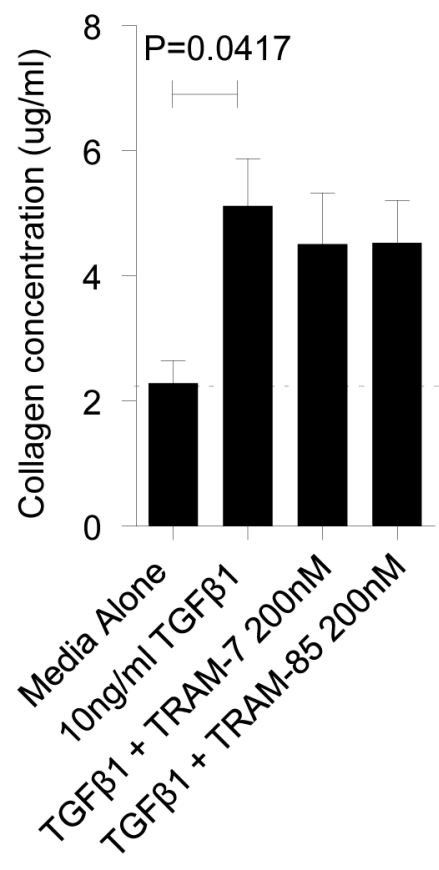

Figure 8. Blocking $\mathrm{K}_{\mathrm{Ca}} 3.1$ channels decreases TGF $\beta$ 1-dependent myofibroblast collagen secretion. a) and b) Collagen secretion was increased in myofibroblasts following TGF $\beta 1$-dependent simulation in both IPF donors $(n=4)$ and NFC donors $(n=4)$, $P=0.0464$, paired t-test (data shown is pooled IPF and NFC which did not differ). a) This TGF 1 -induced increase was inhibited by TRAM-34 $20 \mathrm{nM}$ and $200 \mathrm{nM}(P=0.0161$, repeated measures ANOVA) and there were significant differences found between TGF $\beta 1$ and TRAM-34 $20 \mathrm{nM}$ ( ${ }^{* *} P=0.0473$, corrected by Bonferroni's multiple comparisons test) and between TGF $\beta 1$ and TRAM-34 $200 \mathrm{nM}$ ( ${ }^{* * *} \mathrm{P}=0.0469$, corrected by Bonferroni's multiple comparisons test). b) TGF $\beta 1$-dependent collagen secretion was also inhibited by ICA-17043 ( $P=0.0038$, repeated measures ANOVA), and there were significant differences found between TGF $\beta 1$ and ICA-17043 $10 \mathrm{nM}\left({ }^{* *} P=0.0067\right.$, corrected by Bonferroni's multiple comparisons test) and between TGF $\beta 1$ and ICA-17043 $100 \mathrm{nM}\left({ }^{* * \star} P=0.0039\right.$, corrected by Bonferroni's multiple comparisons test). c) TGF $\beta 1$ increased collagen secretion in myofibroblasts $\left({ }^{\star} P=0.0417\right.$, paired ttest.), however no inhibition of collagen secretion was evident with TRAM-7 or TRAM-85 $(n=3)$. Data represented as mean \pm SEM for all the above figures.

doi: 10.1371/journal.pone.0085244.g008

TGF $\beta 1$ is a key mediator of fibrotic diseases, playing an important role in myofibroblast differentiation [33], matrix protein production [34], and possibly epithelial-mesenchymal transition [35]. TGF $\beta 1$ stimulation increased myofibroblast $\mathrm{K}_{\mathrm{Ca}} 3.1$ mRNA expression, which was greatest in IPF-derived myofibroblasts, and increased the frequency of cells expressing functional membrane channels. bFGF, another key mediator in fibrotic diseases, is a potent chemoattractant and mitogen for myofibroblasts, and regulates extracellular matrix production[34]. bFGF stimulation also increased the frequency of cells expressing $\mathrm{K}_{\mathrm{Ca}} 3.1$ currents (mRNA expression was not studied). These observations are in keeping with bFGF- and TGF $\beta 1$-dependent $\mathrm{K}_{\mathrm{Ca}} 3.1$ upregulation in several cell types [36].
The upregulation of functional $\mathrm{K}_{\mathrm{Ca}} 3.1$ channels by both TGF $\beta 1$ and bFGF suggests that the biological effects of these growth factors might rely heavily on $\mathrm{K}_{\mathrm{Ca}} 3.1$ channel activity. This is supported by the observations that serum-dependent proliferation, serum- and bFGF-dependent myofibroblast wound healing, TGF $\beta 1$-dependent collagen secretion, and both bFGF and TGF $\beta 1$-dependent myofibroblast contraction were attenuated by two distinct and specific $\mathrm{K}_{\mathrm{Ca}} 3.1$ blockers, TRAM-34 and ICA-17043. Importantly, these ion channel blockers inhibited these cell processes at physiologically relevant concentrations. Thus it takes $5-10 x$ the $K_{d}$ to inhibit almost all channels $\left(K_{d}=\right.$ concentration producing $50 \%$ block). The $K_{d}$ for TRAM-34 is $20 \mathrm{nM}$ [11] and for ICA-17043 6-10 nM [10]. At 10x the $K_{d}$ for both blockers, myofibroblast wound 
Figure 9

a)

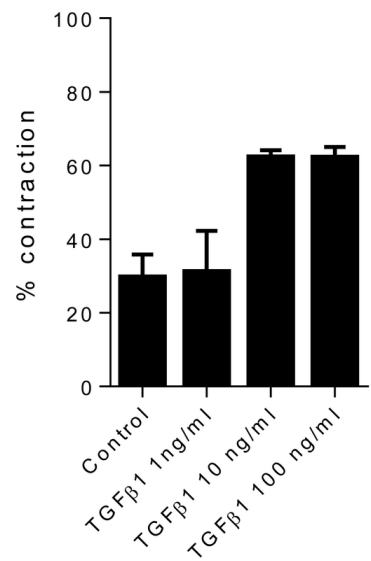

b)

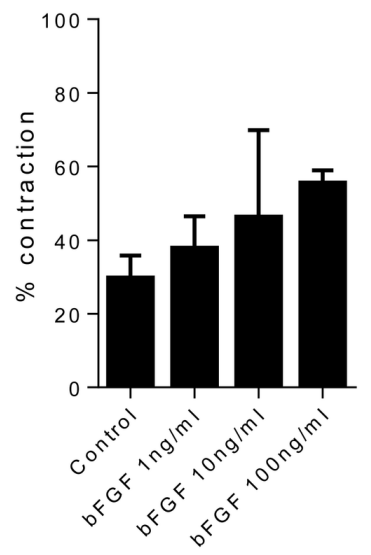

c)

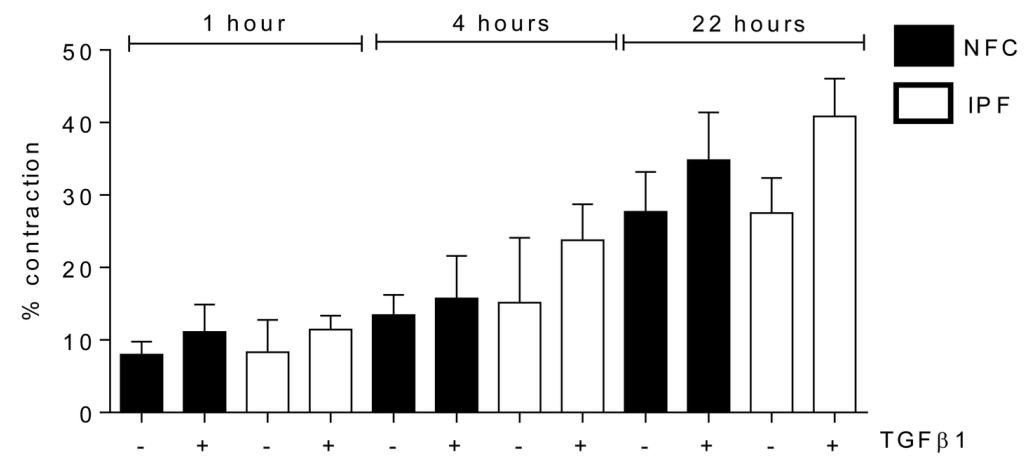

d)

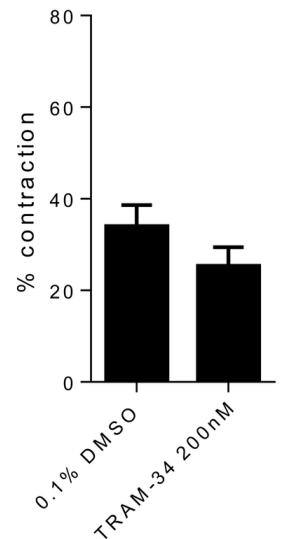

e)

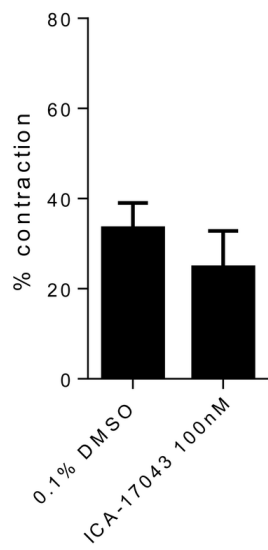

Figure 9. Constitutive unstimulated myofibroblast contraction is not altered by $\mathrm{K}_{\mathrm{ca}} 3.1$ blockade, and $10 \mathrm{ng} / \mathrm{ml}$ of TGF $\beta 1$ and bFGF is optimal concentration. ( $a$ and $b$ ) dose response was performed before beginning experiments which confirmed 10 $\mathrm{ng} / \mathrm{ml}$ as optimal concentration to use for both TGF $\beta 1$ and bFGF in the myofibroblast contraction assay, $\mathrm{n}=2$.c) demonstrates that at the different time points of the contraction assay there were no significant difference between the response of the NFC and IPF cells to TGF $\beta 1$. At 1 hour NFC $n=4$ and IPF $n=3,4$ hours NFC $n=3$, IPF $n=2$ and 22 hours NFC $n=4$ and IPF $n=5$. d) TRAM-34 does not significantly inhibit myofibroblast contraction in the absence of mitogenic stimulation, $n=6$. e) ICA-17043 does not significantly inhibit myofibroblast contraction in the absence of mitogenic stimulation, $n=5$. Data represent mean $\pm S E M$ for all the above figures.

doi: 10.1371/journal.pone.0085244.g009 


\section{Figure 10}

a)

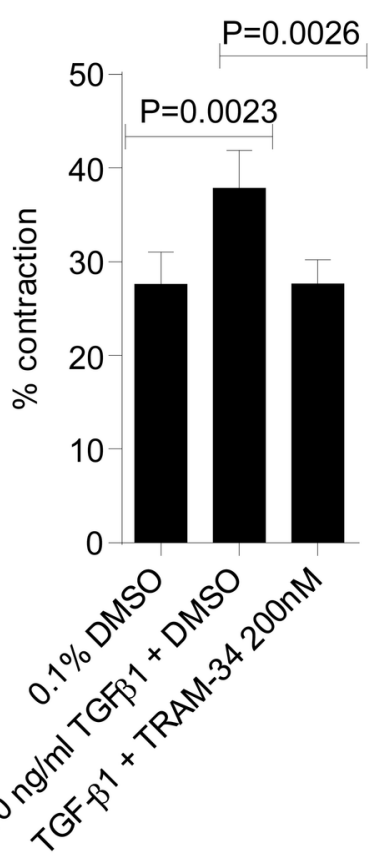

b)
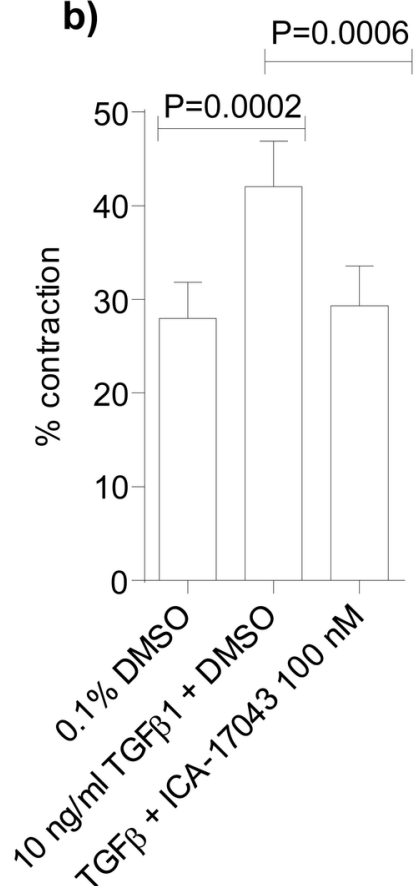

c)

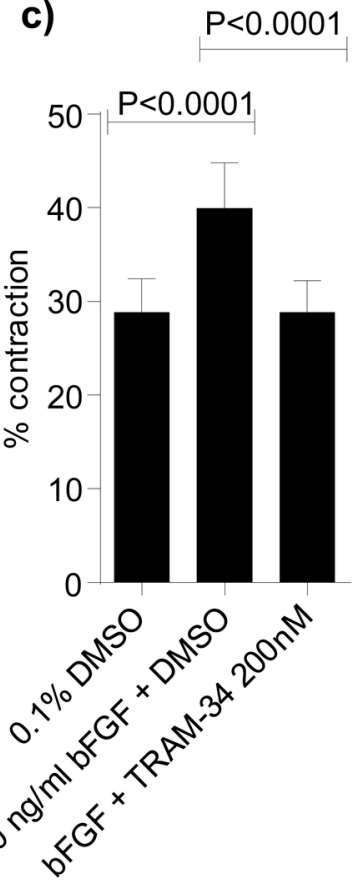

d)

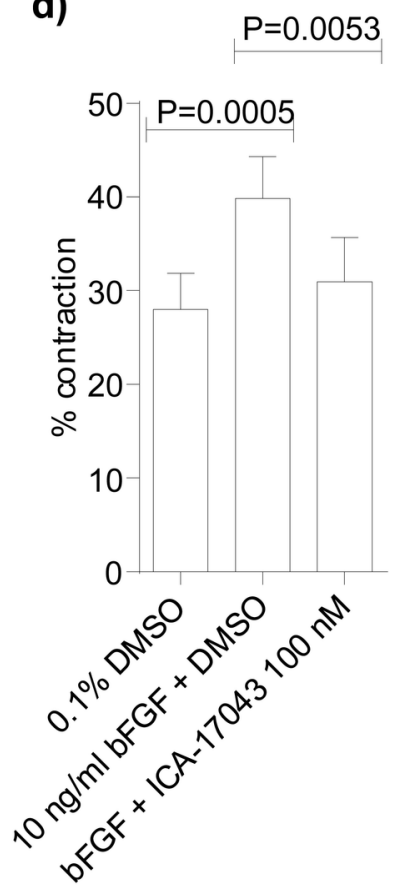

Figure 10. $\mathrm{K}_{\mathrm{Ca}} 3.1$ inhibition TGF $\beta 1$ and bFGF-induced myofibroblast contraction. a) Myofibroblast collagen gel contraction was increased following TGF $\beta 1$ stimulation and this was inhibited by TRAM-34 $200 \mathrm{nM}$ in both IPF ( $n=3)$ and NFC ( $n=3)$ donors (data shown is pooled IPF and NFC which did not differ, $n=6)(P=0.0014$, repeated measures ANOVA, $P=0.0023$ for TGF $\beta 1$ compared to control, $P=0.0026$ for TRAM-34 compared to TGF $\beta 1$ corrected by Bonferroni's multiple comparisons test). b) TGF $\beta 1$ dependent myofibroblast collagen gel contraction was also inhibited by ICA-17043 $100 \mathrm{nM}(\mathrm{n}=6)$ (All groups; repeated measures ANOVA, $P=0.0002$, TGF $\beta 1$ versus control, $P=0.0002$ and for ICA-17043 versus TGF $\beta 1, P=0.0006$, corrected by Bonferroni's multiple comparisons test). c) Similarly, myofibroblast collagen gel contraction was increased following bFGF stimulation and was also inhibited with 24h pre-treatment with TRAM-34 $200 \mathrm{nM}$ (All groups; repeated measures ANOVA $P<0.0001$, for bFGF compared to control, $P<0.0001$, and for TRAM-34 compared to bFGF, $P<0.0001$ (corrected by Bonferroni's multiple comparisons test). d) Similarly, 24h pre-treatment with ICA-17043 $100 \mathrm{nM}$ significantly reduced bFGF-dependent myofibroblast collagen gel contraction $(P=0.0007$, repeated measures ANOVA) $(P=0.0005$ for bFGF versus control and $P=0.0053$ for ICA- 17043 versus bFGF, corrected by Bonferroni's multiple comparisons test). Data represented as mean $\pm \mathrm{SEM}$ for all the above figures.

doi: 10.1371/journal.pone.0085244.g010

healing, collagen secretion and contraction were significantly attenuated. At these concentrations both drugs are specific and not known to affect other ion channels, receptors or transporters [13]. Furthermore, the effects of TRAM-34 and ICA-17043 on myofibroblast biology were not mimicked by TRAM-7 or TRAM-85, two molecules of similar structure to TRAM-34 which do not block $\mathrm{K}_{\mathrm{Ca}} 3.1$ ion channels $[13,28]$.

Upon TGF $\beta 1$ stimulation human lung myofibroblast exhibited a rise in $\left[\mathrm{Ca}^{2+}\right]$ i concentrations which was blocked by TRAM-34. This demonstrates how both membrane hyperpolarization and $\mathrm{Ca}^{2+}$ influx is critical for myofibroblast function in keeping with observations in other cells types $[10,11,26]$, and provides mechanistic insight for the role of $\mathrm{K}_{\mathrm{Ca}} 3.1$ in lung myofibroblast responses.

Although $\mathrm{K}_{\mathrm{Ca}} 3.1$ channels were more highly expressed in IPF myofibroblasts than in NFC cells, the functional responses of the cells to growth factors were largely similar irrespective of their source. This is perhaps not surprising because membrane hyperpolarization can be achieved with as few as 12 channels per cell [32], meaning that $\mathrm{Ca}^{2+}$ dependent cell processes can proceed with very low channel expression. Similar shifts in membrane potential in NFC and IPF myofibroblasts are evident in Figure 3c. However, the presence of significantly more channels in IPF myofibroblasts suggests that it will be more difficult for a physiological process to overcome the effects of the increased channel activity. This however does not apply to channel blockers which will inhibit 10 or 1000 channels equally effectively. Therefore pharmacological $\mathrm{K}_{\mathrm{ca}} 3.1$ blockers are attractive targets as they block all channels and will potentially attenuate pro-fibrotic responses as shown in this study.

$\mathrm{K}_{\mathrm{Ca}} 3.1$ was expressed in both NFC and IPF lung tissue, supporting the relevance of our in vitro findings. In IPF tissue, 


\section{Figure 11}

a)

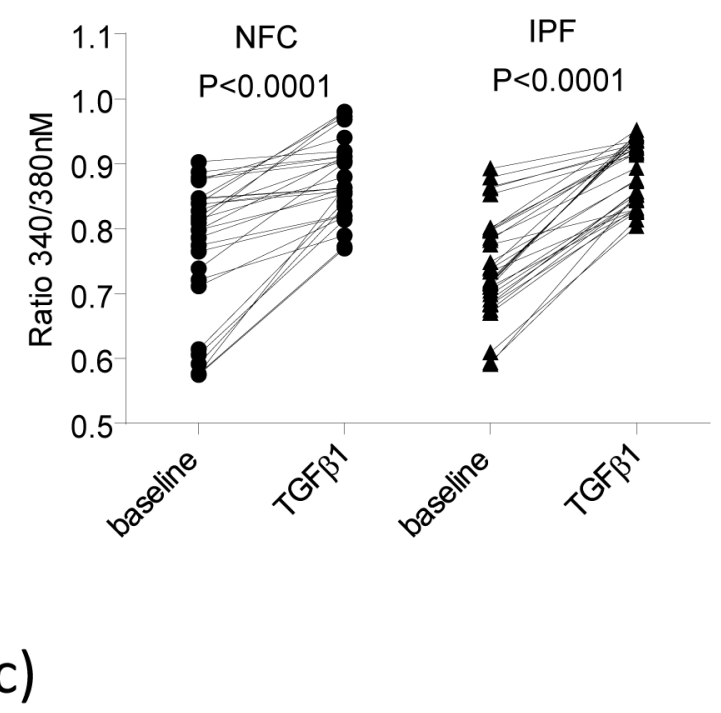

b)

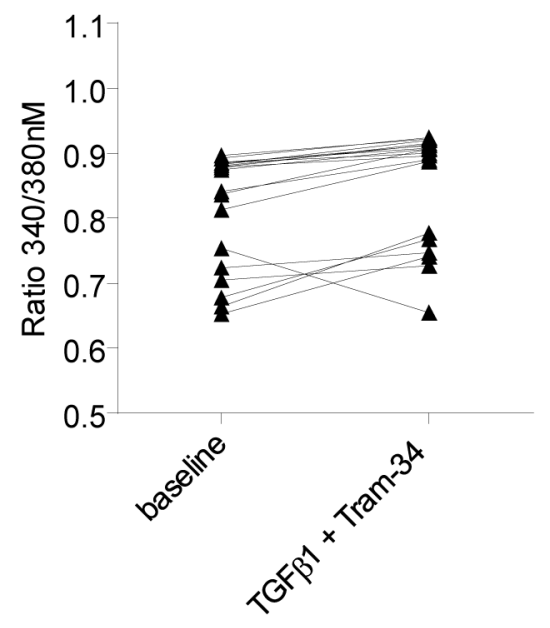

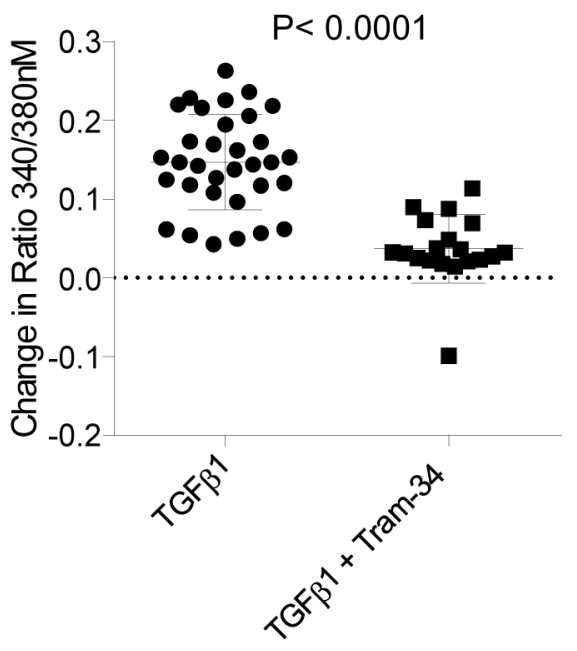

Figure 11. TGF $\beta 1$ induces a rise in intracellular calcium which is inhibited by pharmacological blockade of $\mathrm{K}_{\mathrm{Ca}} 3.1$. Upon stimulation with TGF $\beta 1(10 \mathrm{ng} / \mathrm{ml})$ both NFC ( $\mathrm{n}=4$ donor, $\mathrm{n}=28$ cells) and IPF ( $\mathrm{n}=3$ donors, $\mathrm{n}=33$ cells) donors showed a significant rise in $\left[\mathrm{Ca}^{2+}\right]$ i concentration as displayed the ratio $340 / 380 \mathrm{~nm}, P<0.0001$ for both, paired t-test. b) In IPF only ( $\mathrm{n}=3$ donors and $\mathrm{n}=19$ cells), TRAM-34 (200 nM) was added 5 minutes prior to treatment with TGF $\beta 1$, which inhibited the rise in [Ca $\left.{ }^{2+}\right]$ typically seen upon TGF $\beta 1$ stimulation. c) The difference in $\left[\mathrm{Ca}^{2+}\right]$ i following the different treatments were calculated and TRAM-34 significantly decreased the change in $\left[\mathrm{Ca}^{2+}\right] \mathrm{i}, P<0.0001$, Mann Whitney t-test.

doi: 10.1371/journal.pone.0085244.g011

$\mathrm{K}_{\mathrm{Ca}} 3.1$ was not only expressed in areas of aSMA positivity, but also highly expressed in alveolar epithelial cells, vessels and inflammatory cells. In addition to alveolar epithelial cells, both mast cells and fibrocytes are implicated in IPF progression and express $\mathrm{K}_{\mathrm{Ca}} 3.1[10,26]$. Targeting $\mathrm{K}_{\mathrm{Ca}} 3.1$ in IPF may therefore have additional benefits over and above those achieved through the inhibition of myofibroblast function.

Our data indicate that the $\mathrm{K}_{\mathrm{Ca}} 3.1$ channel may play a key role in the development of lung fibrosis, in both IPF and other lung disorders. $\mathrm{K}_{\mathrm{Ca}} 3.1$ is an attractive pharmacological target as it appears to play a minor role in healthy physiology, but 
contributes significantly to tissue remodeling and fibrosis [37]. It has been suggested that $\mathrm{K}_{\mathrm{Ca}} 3.1$ opening contributes to pulmonary vascular relaxation in rats[38], but this was not the case in human pulmonary vessels[39]. Importantly, $\mathrm{K}_{\mathrm{Ca}} 3.1$ knockout mice are viable, of normal appearance, produce normal litter sizes, and exhibit rather mild phenotypes [13]. High doses of TRAM-34 administered to rodents over many weeks are well tolerated [13] and the orally available $\mathrm{K}_{\mathrm{Ca}} 3.1$ blocker, ICA-17043, has been administered to humans in phase 2 and 3 trials of sickle cell disease with minor side effects [40]. There is therefore the potential for the rapid

\section{References}

1. Raghu G, Collard HR, Egan JJ, Martinez FJ, Behr J et al. (2011) An official ATS/ERS/JRS/ALAT statement: Idiopathic pulmonary fibrosis: Evidence-based guidelines for diagnosis and management. Am J Respir Crit Care Med 183: 788-824. doi:10.1164/rccm.2009-040GL. PubMed: 21471066.

2. Raghu G, Weycker D, Edelsberg J, Bradford WZ, Oster G (2006) Incidence and prevalence of idiopathic pulmonary fibrosis. Am J Respir Crit Care Med 174: 810-816. doi:10.1164/rccm.200602-163OC. PubMed: 16809633

3. Gribbin J, Hubbard RB, Le Jeune I, Smith CJ, West J et al. (2006) Incidence and mortality of idiopathic pulmonary fibrosis and sarcoidosis in the UK. Thorax 61: 980-985. doi:10.1136/thx.2006.062836. PubMed: 16844727

4. Strieter RM (2005) Pathogenesis and natural history of usual interstitial pneumonia: The whole story or the last chapter of a long novel. Chest 128: 526S-532S. doi:10.1378/chest.128.5_suppl_1.526S. PubMed: 16304243.

5. Grinnell F (1994) Fibroblasts, myofibroblasts, and wound contraction. J Cell Biol 124: 401-404. doi:10.1083/jcb.124.4.401. PubMed: 8106541.

6. McAnulty RJ (2007) Fibroblasts and myofibroblasts: Their source, function and role in disease. Int J Biochem Cell Biol 39: 666-671. doi: 10.1016/j.biocel.2006.11.005. PubMed: 17196874.

7. Phan SH (2002) The myofibroblast in pulmonary fibrosis. Chest 122 : 286S-289S. doi:10.1378/chest.122.6_suppl.286S. PubMed: 12475801.

8. Fanger CM, Rauer H, Neben AL, Miller MJ, Rauer H et al. (2001) Calcium-activated potassium channels sustain calcium signaling in $\mathrm{T}$ lymphocytes - selective blockers and manipulated channel expression levels. J Biol Chem 276: 12249-12256. doi:10.1074/jbc.M011342200. PubMed: 11278890

9. Ghanshani S, Wulff H, Miller MJ, Rohm H, Neben A et al. (2000) Upregulation of the IKCa1 potassium channel during T-cell activation. molecular mechanism and functional consequences. J Biol Chem 275: 37137-37149. doi:10.1074/jbc.M003941200. PubMed: 10961988

10. Cruse G, Duffy SM, Brightling CE, Bradding P (2006) Functional $\mathrm{KCa} 3.1 \mathrm{~K}+$ channels are required for human lung mast cell migration. Thorax 61: 880-885. doi:10.1136/thx.2006.060319. PubMed: 16809411.

11. Shepherd MC, Duffy SM, Harris T, Cruse G, Schuliga M et al. (2007) $\mathrm{K}(\mathrm{ca}) 3.1 \mathrm{Ca} 2+$-activated $\mathrm{K}+$ channels regulate human airway smooth muscle proliferation. Am J Respir Cell Mol Biol 37: 525-531. doi: 10.1165/rcmb.2006-03580C. PubMed: 17585114

12. Duffy S, Berger P, Cruse G, Yang W, Bolton SJ et al. (2004) The K+ channel iKCA1 potentiates $\mathrm{Ca} 2+$ influx and degranulation in human lung mast cells. J Allergy Clin Immunol 114: 66-72. doi:10.1016/j.jaci. 2004.04.005. PubMed: 15241346.

13. Grgic I, Kiss E, Kaistha BP, Busch C, Kloss M et al. (2009) Renal fibrosis is attenuated by targeted disruption of $\mathrm{KCa} 3.1$ potassium channels. Proc Natl Acad Sci U S A 106: 14518-14523. doi:10.1073/ pnas.0903458106. PubMed: 19706538.

14. Keira SM, Ferreira LM, Gragnani A, Duarte Ids Santos, Anunciação Isabel Neves dos (2004) Experimental model for fibroblast culture. Acta Cirurgica Bras 19: 11-16

15. Pilewski JM, Liu LX, Henry AC, Knauer AV, Feghali-Bostwick CA (2005) Insulin-like growth factor binding proteins 3 and 5 are overexpressed in idiopathic pulmonary fibrosis and contribute to extracellular matrix deposition. Am J Pathol 166: 399-407. doi:10.1016/ S0002-9440(10)62263-8. PubMed: 15681824.

16. Hamill OP, Marty A, Neher E, Sakmann B, Sigworth FJ (1981) Improved patch-clamp techniques for high-resolution current recording investigation of $\mathrm{K}_{\mathrm{Ca}} 3.1$ blockade in clinical trials of IPF and other fibrotic lung diseases.

\section{Author Contributions}

Conceived and designed the experiments: PB KMR CF-B HW SMD. Performed the experiments: KMR. Analyzed the data: KMR PB HW WC CF-B SMD. Contributed reagents/materials/ analysis tools: KMR PB HW WC CF-B SMD. Wrote the manuscript: PB KMR. Revised manuscript critically for intellectual content: HW WC CF-B SMD.

from cells and cell-free membrane patches. Pflugers Arch 391: 85-100. doi:10.1007/BF00656997. PubMed: 6270629

17. Duffy SM, Lawley WJ, Conley EC, Bradding P (2001) Resting and activation-dependent ion channels in human mast cells. J Immunol 167: 4261-4270. PubMed: 11591748

18. Wulff H, Miller MJ, Hansel W, Grissmer S, Cahalan MD et al. (2000) Design of a potent and selective inhibitor of the intermediateconductance $\mathrm{Ca} 2+$-activated $\mathrm{K}+$ channel, IKCa1: A potential immunosuppressant. Proc Natl Acad Sci U S A 97: 8151-8156. doi: 10.1073/pnas.97.14.8151. PubMed: 10884437.

19. Stocker JW, De Franceschi L, McNaughton-Smith GA, Corrocher R, Beuzard $Y$ et al. (2003) ICA-17043, a novel gardos channel blocker, prevents sickled red blood cell dehydration in vitro and in vivo in SAD mice. Blood 101: 2412-2418. doi:10.1182/blood-2002-05-1433. PubMed: 12433690.

20. Huang M, Sharma S, Zhu LX, Keane MP, Luo J et al. (2002) IL-7 inhibits fibroblast TGF-beta production and signaling in pulmonary fibrosis. J Clin Invest 109: 931-937. doi:10.1172/JCl14685. PubMed: 11927620.

21. Distler JHW, Jüngel A, Huber LC, Schulze-Horsel U, Zwerina J et al. (2007) Imatinib mesylate reduces production of extracellular matrix and prevents development of experimental dermal fibrosis. Arthritis Rheum 56: 311-322. doi:10.1002/art.22314. PubMed: 17195235.

22. Woodman L, Siddiqui S, Cruse G, Sutcliffe A, Saunders R et al. (2008) Mast cells promote airway smooth muscle cell differentiation via autocrine up-regulation of TGF- $\beta 1$. Journal of Immunology 181: 5001-5007. PubMed: 18802103

23. Duffy SM, Lawley WJ, Kaur D, Yang W, Bradding P (2003) Inhibition of human mast cell proliferation and survival by tamoxifen in association with ion channel modulation. J Allergy Clin Immunol 112: 965-972. doi: 10.1016/j.jaci.2003.07.004. PubMed: 14610489.

24. Chen MX, Gorman SA, Benson B, Singh K, Hieble JP et al. (2004) Small and intermediate conductance ca 2 +-activated $\mathrm{K}^{+}$channels confer distinctive patterns of distribution in human tissues and differential cellular localisation in the colon and corpus cavernosum. Naunyn Schmiedebergs Arch Pharmacol 369: 602-615. doi:10.1007/ s00210-004-0934-5. PubMed: 15127180.

25. Ohya S, Niwa S, Yanagi A, Fukuyo $Y$, Yamamura $H$ et al. (2011) Involvement of dominant-negative spliced variants of the intermediate conductance Ca2+-activated $\mathrm{K}+$ channel, $\mathrm{KCa} 3.1$, in immune function of lymphoid cells. J Biol Chem 286: 16940-16952. doi:10.1074/ jbc.M110.184192. PubMed: 21345794.

26. Cruse G, Singh SR, Duffy SM, Doe C, Saunders R, et al. (2011) Functional KCa3.1 K+ channels are required for human fibrocyte migration. J Allergy Clin Immunol 128: 1303-1309.e2

27. Pedersen KA, Schrøder RL, Skaaning-Jensen B, Strøbaek D, Olesen SP et al. (1999) Activation of the human intermediate-conductance ca(2+)-activated $\mathrm{K}(+)$ channel by 1-ethyl-2-benzimidazolinone is strongly ca(2+)-dependent. Biochim Biophys Acta 1420: 231-240. doi: 10.1016/S0005-2736(99)00110-8. PubMed: 10446306.

28. Köhler R, Wulff H, Eichler I, Kneifel M, Neumann D et al. (2003) Blockade of the intermediate-conductance calcium-activated potassium channel as a new therapeutic strategy for restenosis. Circulation 108: 1119-1125. doi:10.1161/01.CIR.0000086464.04719.DD. PubMed: 12939222.

29. Zhou X, Wu W, Hu H, Milosevic J, Konishi K et al. (2011) Genomic differences distinguish the myofibroblast phenotype of distal lung from airway fibroblasts. Am J Respir Cell Mol Biol.

30. Kotaru C, Schoonover KJ, Trudeau JB, Huynh ML, Zhou X et al. (2006) Regional fibroblast heterogeneity in the lung: Implications for 
remodeling. Am J Respir Crit Care Med 173: 1208-1215. doi:10.1164/ rccm.200508-12180C. PubMed: 16543551.

31. Koegel H, Kaesler S, Burgstahler R, Werner S, Alzheimer C (2003) Unexpected down-regulation of the hlK1 Ca2+-activated $\mathrm{K}+$ channel by its opener 1-ethyl-2-benzimidazolinone in $\mathrm{HaCaT}$ keratinocytes. J Biol Chem 278: 3323-3330. PubMed: 12421833.

32. Bi D, Toyama K, Lemaître V, Takai J, Fan F et al. (2013) The intermediate conductance calcium-activated potassium channel KCa3.1 regulates vascular smooth muscle cell proliferation via controlling calcium-dependent signaling. J Biol Chem 288: 15843-15853. doi: 10.1074/jbc.M112.427187. PubMed: 23609438.

33. Thannickal VJ, Lee DY, White ES, Cui Z, Larios JM et al. (2003) Myofibroblast differentiation by transforming growth factor-beta1 is dependent on cell adhesion and integrin signaling via focal adhesion kinase. J Biol Chem 278: 12384-12389. doi:10.1074/jbc.M208544200. PubMed: 12531888.

34. Raghu G, Masta S, Meyers D, Narayanan AS (1989) Collagen synthesis by normal and fibrotic human lung fibroblasts and the effect of transforming growth factor-beta. Am Rev Respir Dis 140: 95-100. doi:10.1164/ajrccm/140.1.95. PubMed: 2751176.

35. Willis BC, Borok Z (2007) TGF-beta-induced EMT: Mechanisms and implications for fibrotic lung disease. Am J Physiol Lung Cell Mol Physiol 293: L525-L534. doi:10.1152/ajplung.00163.2007. PubMed: 17631612.
36. Grgic I, Eichler I, Heinau P, Si H, Brakemeier S et al. (2005) Selective blockade of the intermediate-conductance $\mathrm{Ca} 2+$-activated $\mathrm{K}+$ channel suppresses proliferation of microvascular and macrovascular endothelial cells and angiogenesis in vivo. Arterioscler Thromb Vasc Biol 25: 704-709. doi:10.1161/01.ATV.0000156399.12787.5c. PubMed: 15662023.

37. Wulff H, Castle NA (2010) Therapeutic potential of KCa3.1 blockers: Recent advances and promising trends. Expert Rev Clin Pharmacol 3: 385-396. doi:10.1586/ecp.10.11. PubMed: 22111618.

38. Stankevicius E, Dalsgaard T, Kroigaard C, Beck L, Boedtkjer E et al. (2011) Opening of small and intermediate calcium-activated potassium channels induces relaxation mainly mediated by nitric-oxide release in large arteries and endothelium-derived hyperpolarizing factor in small arteries from rat. J Pharmacol Exp Ther 339: 842-850. doi:10.1124/jpet. 111.179242. PubMed: 21880870.

39. Kroigaard C, Dalsgaard T, Nielsen G, Laursen BE, Pilegaard $\mathrm{H}$ et al. (2012) Activation of endothelial and epithelial KCa2.3 calcium-activated potassium channels by NS309 relaxes human small pulmonary arteries and bronchioles. $\mathrm{Br} \mathrm{J}$ Pharmacol 167: 37-47. doi:10.1111/j. 1476-5381.2012.01986.x. PubMed: 22506557.

40. Ataga KI, Smith WR, De Castro LM, Swerdlow P, Saunthararajah Y et al. (2008) Efficacy and safety of the gardos channel blocker, senicapoc (ICA-17043), in patients with sickle cell anemia. Blood 111: 3991-3997. doi:10.1182/blood-2007-08-110098. PubMed: 18192510. 